\title{
Mixed carbonate-siliciclastic sedimentation in a mesoproterozoic storm-dominated ramp: Depositional processes and stromatolite development
}

\author{
João Pedro Formolo Ferronatto ${ }^{\mathrm{a},}{ }_{*}$, Claiton Marlon dos Santos Scherer ${ }^{\mathrm{a}}$, Gabriel Barbosa Drago ${ }^{\mathrm{a}}$, \\ Amanda Goulart Rodrigues ${ }^{a}$, Ezequiel Galvão de Souza ${ }^{b}$, Adriano Domingos dos Reis ${ }^{a}$, \\ Manoela Bettarel Bállico ${ }^{\mathrm{c}}$, Carrel Kifumbi ${ }^{\mathrm{a}}$, Caroline Lessio Cazarin ${ }^{\mathrm{d}}$ \\ ${ }^{a}$ Instituto de Geociencias, Universidade Federal do Rio Grande do Sul, Campus do Vale, Av. Bento Gonçalves, 950091509-900 Porto Alegre/RS, Brazil \\ ${ }^{\mathrm{b}}$ Universidade Federal do Pampa (Unipampa), Campus Caçapava do Sul. Av. Pedro Anunciação, 111 - Vila Batista, 96570-000, Caçapava do Sul/RS, Brazil \\ ${ }^{\mathrm{c}}$ Departamento de Geociências, Universidade Federal de Santa Catarina, Campus Universitário, 88040-900, Florianópolis/SC, Brazil \\ ${ }^{\text {d } C E N P E S ~-~ P e t r o ́ l e o ~ B r a s i l e i r o ~ S . A . ~(P E T R O B R A S), ~ 21941-915 ~ R i o ~ d e ~ J a n e i r o / R J, ~ B r a z i l ~}$
}

\section{A R T I C L E I N F O}

\section{Keywords:}

Proterozoic

Caboclo Formation

Sediment mixing

Hybrid sediments

Precambrian stromatolites

\begin{abstract}
A B S T R A C T
Records of shallow-marine ramps with the mixing of carbonate and siliciclastic sediments are common throughout the geological time. All these records have pure carbonate and pure siliciclastic deposits as end members, occurring contemporaneously in distinct depositional regions along the ramp, and transitional hybrid facies between them. The two end member can mix in different scales and can alternate in time due to climatic changes and regressions and transgressions. This work presents a detailed reconstruction of a Mesoproterozoic storm-dominated mixed carbonate-siliciclastic ramp composed of hybrid sediments and whithout the presence of pure siliciclastic or carbonate deposits, a rare example in the geological record. Based on a high resolution logged section (in 1:20 scale) and qualitative thin sections, eleven lithofacies were identified and grouped into three lithofacies associations (offshore, offshore transition and shoreface), which are stacked vertically forming a transgressive-regressive cycle. This faciological distribution indicates a low relief ramp with wide microbial colonization from shallow to relatively deep waters (below storm-wave base level). In offshore low-energy distal areas, microbial mats spread laterally over large distances with little or no interference from currents, while in the offshore transition the morphology of the bioherms is shaped by currents induced by waves. In turn, the high wave energy in the shoreface inhibits the formation of stromatolites, restricting their occurrence to thin layers of microbial carpets or intraclastic lags. The mixing occurs in compositional scale and is relatively homogeneous along the whole logged interval, independent of the shifts in lithofacies or lithofacies associations. This compositional homogeneity is linked to the wide distribution and regularity in the input of siliciclastic sediments during the sedimentary accumulation. Strong currents induced by storms allow the transport and mixing of siliciclastic sediments with carbonate grains generated in the basin during fair-weather periods.
\end{abstract}

\section{Introduction}

Mixed carbonate-siliciclastic shallow-marine systems are quite common throughout the geological history. These environments display variable mixing and resultant heterogeneity of different scales (stratigraphic, stratic and compositional - Mount, 1984; Chiarella et al., 2017). The reported examples cover several ages (e.g., Neoproterozoic - Haines, 1988; Saylor, 2003; Dibenedetto and Grotzinger, 2005; Paleozoic - Barnaby and
Ward, 2007; Gomez and Astini, 2015; Labaj and Pratt, 2016; Mesozoic Spalletti et al., 2000; Sanders and Höfling, 2000; Schwarz et al., 2016; Cenozoic - Tucker, 2003; Scheibner et al., 2003; Thrana and Talbot, 2006). The major characteristic shared with all the examples is represented by the presence of pure carbonate and pure siliciclastic end member deposits occurring contemporaneously in distinct depositional environments of the ramp, and the hybrid sedimentation (Zuffa, 1980) dominating in a transitional zone between the two end members (Schwarz

\footnotetext{
* Corresponding author.

E-mail address: joaopedroformolo@hotmail.com (J.P.F. Ferronatto).
} 




Fig. 1. (A) Simplified geological map based on data from Brazilian Geological Survey (CPRM) and key chart with the stratigraphy of Chapada Diamantina modified from from Guadagnin et al. (2015). The map shows the location of Morro do Chapéu town and Cristal Cave outcrop. The inset shows location of São Francisco Craton in Brazil (in black). (B) Inside the cave. The lower portion of the outcrop. (C) Scarp where the upper portion of the outcrop was logged. In B and C it's possible to observe the tabular geometry of the sedimentary packages. et al., 2018). The sedimentary composition of the mixed system is intimately associated to the processes responsible for carbonate production (skeletal and non-skeletal) and the source area of siliciclastic input in the basin. The mixture depends on the hydrodynamic processes acting on the coast and how the sediments are distributed.

The microbialites are common in Proterozoic successions. Their distribution and spatial evolution are influenced by detrital input and the depositional settings. Although several studies have illustrated the widespread occurrence of stromatolites (Logan et al., 1964; Walter, 1977; Awramik and Riding, 1988; Riding, 1991, 2000; Frantz et al., 2015), few studies demonstrate how the influx of different sediments (i.e., siliciclastic or carbonate) and sedimentary process related to normal and/or storm waves control the morphology, distribution and preservation of stromatolites in Proterozoic mixed carbonate-siliclastic ramp (Hoffman, 1974; Beukes, 1987; Haines, 1988; Saylor, 2003).

This study focuses on a portion of the Caboclo Formation, Mesoproterozoic of Chapada Diamantina, Brazil. Based on a high-resolution section (logged in 1:20 scale), and on the qualitative thin section, a mixed carbonate-siliciclastic system with a wide distribution of stromatolites was possibly classified via petrographic analysis. The mixing occurs in compositional scale and is relatively homogeneous along the whole logged interval, independent of the shifts in lithofacies or lithofacies associations. This makes the Caboclo Formation a rather unique example in the geological record, since, in most cases, the degree of mixing of carbonate and siliciclastic grains is usually considered to vary laterally within the same depositional context (Schwarz et al., 2018).

This paper provide a detailed reconstruction of a Mesoproterozoic mixed carbonate-siliciclastic storm-dominated ramp composed entirely of hybrid sediments. The specific goals include (i) to define the different processes controlling the ramp morphology and the stromatolite distribution; (ii) to classify the relationship between the distribution of carbonate and siliciclastic grains and the process of mixing; (iii) to construct a depositional model.

\section{Geological setting}

The Mesoproterozoic Stenian Caboclo Formation, part of Espinhaço Supergroup, crops out in central-northern region of São Francisco Craton, in physiographic region of Chapada Diamantina Domain on Paramirim Aulacogen (Fig. 1A). During Arquean and Paleoproterozoic, São Francisco Craton and Congo Craton belonged to the Rodinia Supercontinent (Brito Neves et al, 1999; Campos Neto, 2000). The Espinhaço Supergroup was deposited after the amalgamation of these two cratons at $1.8 \mathrm{Ga}$ and before partial break-up at $0.9 \mathrm{Ga}$, and is interpreted as being formed in intracontinental rift-sag basins (Brito Neves et al., 1979; Chemale et al., 1993; Martins-Neto, 2000; Alkmim and Martins-Neto, 2012; Guadagnin et al., 2015). During the Neoproterozoic Brasiliano event, the basin suffered a partial inversion, leading to the development of a series of NNW-trending folds and thrust faults (Marshak and Alkmim, 1989; Cruz and Alkmim, 2006).

According to Chemale et al. (2012) and Guadagnin et al. (2015), the Espinhaço Supergroup is divided into three 1st-order megasequences, i. e., Lower, Middle and Upper Espinhaço (Fig. 1A). Of these, the Upper Espinhaço (1.19 to $0.9 \mathrm{Ga}$ ) consists of the Caboclo Formation and Morro do Chapéu Formation at Chapada Diamantina domain. The Caboclo Formation, unconformably overlain by the Morro do Chapéu Formation, is paraconformably underlain by alluvial/aeolian deposits of Tombador Formation (Middle Espinhaço megasequence). Thus, the Caboclo and 


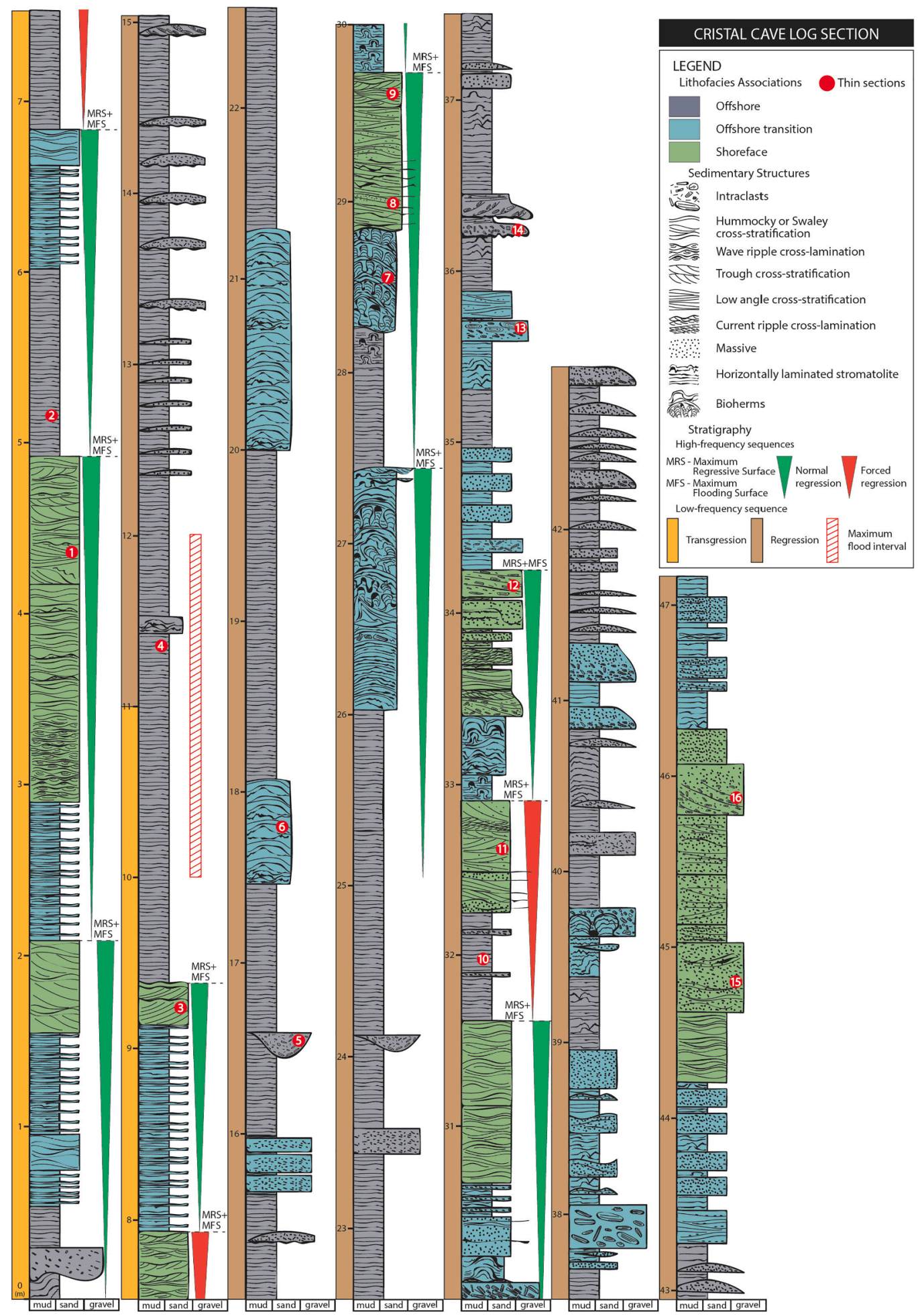

Fig. 2. Cristal Cave log section with stratigraphic interpretation. The base interval of the section represents the transgressive systems tract (TST), followed by a long regressive systems tract (RST), separated by a maximum flood interval.

Morro do Chapéu formations are distinct 2nd-order sequences nested in the Upper 1st-order megasequence (Guadagnin et al., 2015).

The Mesoproterozoic Caboclo Formation was interpreted as a mixed siliciclastic-carbonate storm-dominated ramp (Branner, 1910; Pedreira, 1994) situated at low latitude (Pesonen et al., 2012; Pisarevsky et al., 2014). This formation consists mainly of siliciclastic (mudstones and sandstones) and carbonate to siliciclastic-carbonate deposits named as Jacuipe Flint by Branner (1910) and classified as the carbonate interval of Caboclo Formation by various authors (e.g., Srivastava, 1988; Rocha et al., 1992; Babinski et al., 1993; Souza et al., 2021). Depositional age of Caboclo Formation carbonates was dated by radiometric $\mathrm{Pb}-\mathrm{Pb}$ method at $1140 \pm 140 \mathrm{Ma}$ (Babinski et al., 1993).

\section{Study area and methods}

The Cristal Cave section is one key natural outcrop that was analyzed in detail in this paper, in which the Caboclo Formation presents an excellent 
Table 1

Lithofacies summary.

\begin{tabular}{|c|c|c|c|}
\hline Facies & Code & Description & Interpretation \\
\hline $\begin{array}{l}\text { Massive hybrid } \\
\text { conglomerate/ } \\
\text { rudstone }\end{array}$ & $\mathrm{Gm}$ & $\begin{array}{l}\text { Matrix- or clast- } \\
\text { supported, poorly } \\
\text { sorted, massive } \\
\text { intraformational sandy } \\
\text { conglomerate to } \\
\text { conglomerate. Sandy } \\
\text { matrix composed of } \\
\text { fine- to medium- } \\
\text { grained allochemic } \\
\text { grains and subangular } \\
\text { to subrounded, very } \\
\text { fine- to fine-grained } \\
\text { siliciclastic particles. } \\
\text { Intraclasts vary from } \\
\text { granule to cobble ( }<10 \\
\text { cm), subangular to } \\
\text { rounded, usually with } \\
\text { elongated tabular } \\
\text { shape. Oncolites up to } \\
10 \text { cm. The beds are } \\
\text { continuous or } \\
\text { lenticular, < } 30 \mathrm{~cm} \\
\text { thick, sometimes with } \\
\text { normal gradation and } \\
\text { erosive base (Fig. } 4 \mathrm{~A} \\
\text { and B). }\end{array}$ & $\begin{array}{l}\text { Rapid sedimentation of } \\
\text { coarse sediments from } \\
\text { turbulent flows. Hyper- } \\
\text { concentrated gravity } \\
\text { flows. Post-depositional } \\
\text { fluidization processes } \\
\text { obliterating the } \\
\text { depositional } \\
\text { stratification. }\end{array}$ \\
\hline $\begin{array}{l}\text { Trough cross- } \\
\text { stratified } \\
\text { hybrid } \\
\text { conglomerate/ } \\
\text { rudstone }\end{array}$ & Gt & $\begin{array}{l}\text { Matrix- or clast- } \\
\text { supported, poorly } \\
\text { sorted, trough cross- } \\
\text { stratified, } \\
\text { intraformational, sandy } \\
\text { conglomerate. Sandy } \\
\text { matrix composed of } \\
\text { fine- to medium- } \\
\text { grained allochemic } \\
\text { grains and subangular } \\
\text { to subrounded, very } \\
\text { fine- to fine-grained } \\
\text { siliciclastic particles. } \\
\text { Trough cross- } \\
\text { stratification forming } \\
\text { sets ranging from } 20 \text { to } \\
30 \text { cm. Intraclasts vary } \\
\text { from granule to cobble } \\
\text { ( }<15 \text { cm), subangular } \\
\text { to rounded, usually } \\
\text { with elongated tabular } \\
\text { shape oriented parallel } \\
\text { to stratification, } \\
\text { sometimes imbricated. } \\
\text { The beds have } \\
\text { lenticular geometry and } \\
\text { erosive base (Fig. } 4 \mathrm{~A} \\
\text { and C). }\end{array}$ & $\begin{array}{l}\text { Migration of subaqueous, } \\
\text { sinuous-crested gravel } \\
\text { dunes under } \\
\text { unidirectional flow. }\end{array}$ \\
\hline $\begin{array}{l}\text { Massive hybrid } \\
\text { arenite }\end{array}$ & Sm & $\begin{array}{l}\text { Fine- to coarse-grained, } \\
\text { moderate to poorly } \\
\text { sorted, massive arenite. } \\
\text { Granules and pebbles } \\
\text { are frequent,occurring } \\
\text { sparsely or } \\
\text { concentrated at the } \\
\text { base of the bed. } \\
\text { Allochemics are fine- to } \\
\text { coarse-grained and } \\
\text { siliciclastics are } \\
\text { subangular to rounded, } \\
\text { very fine- to fine- } \\
\text { grained. Tabular or } \\
\text { lenticular bed }<30 \mathrm{~cm} \\
\text { thick (Fig. 4D). }\end{array}$ & $\begin{array}{l}\text { Deposition from } \\
\text { subaqueous hyper- } \\
\text { concentrated gravity } \\
\text { flows or resulting from } \\
\text { post-depositional } \\
\text { fluidization, obliterating } \\
\text { the primary depositional } \\
\text { structure. }\end{array}$ \\
\hline $\begin{array}{l}\text { Low angle } \\
\text { laminated } \\
\text { hybrid arenite }\end{array}$ & S1 & $\begin{array}{l}\text { Fine- to medium- } \\
\text { grained, moderately } \\
\text { sorted arenite, with low } \\
\text { angle lamination }\end{array}$ & $\begin{array}{l}\text { Migration of attenuated } \\
\text { bedforms under the } \\
\text { influence of critical } \\
\text { unidirectional currents }\end{array}$ \\
\hline
\end{tabular}

Table 1 (continued)

\begin{tabular}{|c|c|c|c|}
\hline Facies & Code & Description & Interpretation \\
\hline & & $\begin{array}{l}\left(<15^{\circ}\right) \text {. Medium- } \\
\text { grained allochemic } \\
\text { grains and very fine- to } \\
\text { fine-grained, } \\
\text { subangular to rounded } \\
\text { siliciclastic grains. } \\
\text { Intraclasts are common. } \\
\text { Sets }<15 \mathrm{~cm} \text {, with } \\
\text { erosive base and flat to } \\
\text { slightly undulated top ( } \\
\text { Fig. } 4 \mathrm{G} \text { and } \mathrm{H} \text { ). }\end{array}$ & $\begin{array}{l}\text { associated with } \\
\text { oscillatory flows } \\
\text { (combined flow regime). }\end{array}$ \\
\hline $\begin{array}{l}\text { Trough cross- } \\
\text { stratified } \\
\text { hybrid arenite }\end{array}$ & St & $\begin{array}{l}\text { Fine- to medium- } \\
\text { grained, moderate to } \\
\text { poorly sorted, small- } \\
\text { scale trough cross- } \\
\text { stratified arenite. } \\
\text { Medium-grained } \\
\text { allochemic grains and } \\
\text { very fine- to fine- } \\
\text { grained, subangular to } \\
\text { rounded, siliciclastic } \\
\text { grains. Amalgamated } \\
\text { sets ( } 5 \text { - } 30 \text { cm thick) } \\
\text { with flat to slightly } \\
\text { undulated top (Fig. 4E). }\end{array}$ & $\begin{array}{l}\text { Migration of sinuous- } \\
\text { crested subaqueous } \\
\text { bedforms under } \\
\text { unidirectional to } \\
\text { combined flow regime. }\end{array}$ \\
\hline $\begin{array}{l}\text { Ripple cross- } \\
\text { laminated } \\
\text { hybrid arenite }\end{array}$ & Sr & $\begin{array}{l}\text { Very fine- to fine- } \\
\text { grained, moderately } \\
\text { sorted arenite, with } \\
\text { small-scale asymmetric } \\
\text { ripple cross-lamination } \\
(<4 \mathrm{~cm} \text { ). The climbing } \\
\text { angle vary from } \\
\text { subcritical to critical ( } \\
\text { Fig. } 4 \mathrm{~F}) .\end{array}$ & $\begin{array}{l}\text { Migration of ripples under } \\
\text { unidirectional lower flow } \\
\text { regime. }\end{array}$ \\
\hline $\begin{array}{l}\text { Swaley cross- } \\
\text { stratified } \\
\text { hybrid arenite }\end{array}$ & Sscs & $\begin{array}{l}\text { Very fine- to medium- } \\
\text { grained, moderately to } \\
\text { poorly sorted arenite. } \\
\text { Allochemic grains are } \\
\text { fine- to medium- } \\
\text { grained and } \\
\text { siliciclastics are } \\
\text { subangular to rounded, } \\
\text { very fine- to fine- } \\
\text { grained. Cut and fill } \\
\text { structures with } \\
\text { undulated edges, filled } \\
\text { by small-scale sets } \\
\text { (<20 cm) of } \\
\text { accretionary undulated } \\
\text { lamination, low angle } \\
\text { lamination and/or } \\
\text { trough/sigmoidal cross- } \\
\text { stratification. } \\
\text { Intraclasts are common } \\
\text { at the base of the sets ( } \\
\text { Fig. } 4 \mathrm{H} \text { ). }\end{array}$ & $\begin{array}{l}\text { Migration of symmetric } \\
\text { bedforms, isotropic to } \\
\text { anisotropic, with high } \\
\text { wavelength/amplitude } \\
\text { ratio in conditions of } \\
\text { combined flows regime. } \\
\text { High-intensity storm } \\
\text { conditions. }\end{array}$ \\
\hline $\begin{array}{l}\text { Hummocky cross- } \\
\text { stratified } \\
\text { hybrid arenite }\end{array}$ & Shes & $\begin{array}{l}\text { Fine- to medium- } \\
\text { grained, moderately to } \\
\text { poorly sorted arenite. } \\
\text { Allochemic particles } \\
\text { are fine- to coarse- } \\
\text { grained and siliciclastic } \\
\text { grains are very fine- to } \\
\text { fine grained. The beds } \\
\text { vary from } 10 \text { to } 40 \mathrm{~cm} \\
\text { thick and the thickness } \\
\text { varies laterally. Top } \\
\text { surfaces are undulated } \\
\text { (wavelength from } 0.4 \text { to } \\
2 \text { m). Internally the } \\
\text { lamination can be } \\
\text { isotropic undulated, } \\
\text { scour and drape or } \\
\text { anisotropic trough cross } \\
\text { stratification. Wave } \\
\text { ripples occur at }\end{array}$ & $\begin{array}{l}\text { Symmetric bedforms, } \\
\text { isotropic to anisotropic } \\
\text { with a high wavelength/ } \\
\text { amplitude ratio under } \\
\text { high intensity oscillatory } \\
\text { to combined flow. Wave } \\
\text { ripples represent the } \\
\text { attenuation of the flow. }\end{array}$ \\
\hline
\end{tabular}


Table 1 (continued)

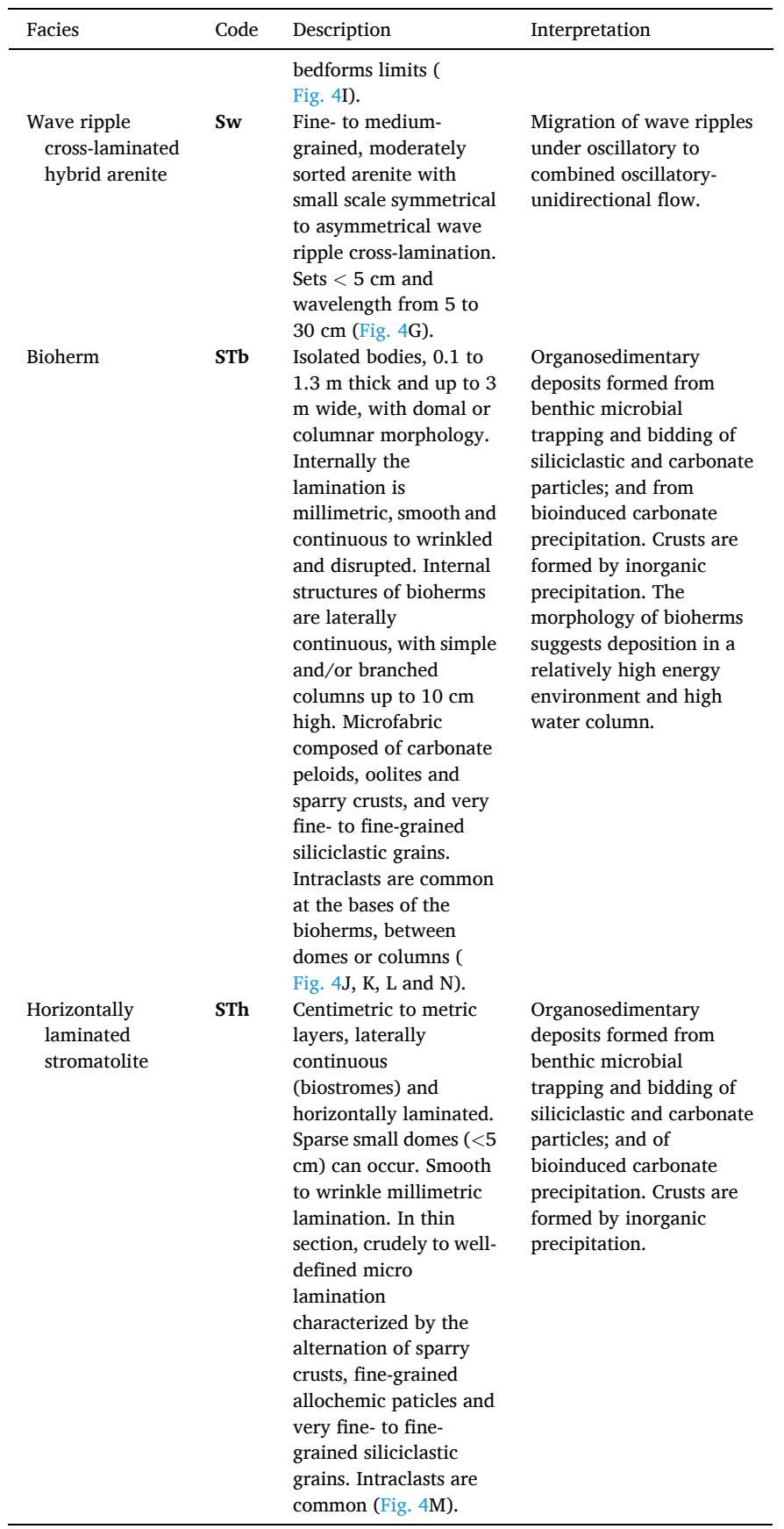

exposure. The section is located approximately $30 \mathrm{~km} \mathrm{SW}$ from Morro do Chapéu city in a region with many dolines and caves (Fig. 1A). The lower half of the outcrop is inside the cave and the upper half is a scarp on the surface (Fig. 1B and C). A $47 \mathrm{~m}$ thick sedimentological log (Fig. 2) was measured and described bed-by-bed at 1:20 scale. The lithofacies were identified via the classical methods of facies analysis (Walker and James, 1992), according to their texture, sedimentary structures, set geometry and lateral transitions. The lithofacies code was based on grain-size (capital letters; i.e., sand ' $S$ ', gravel ' $G$ ') and sedimentary structures (small letters; i. e., massive ' $m$ ', low angle ' 1 ', wave ripples ' $w$ '), following the scheme propoused by Miall (1996). To code the stromatolites was used 'ST', followed by 'b' if they are bioherms or ' $h$ ' if they are horizontally laminated. Genetically related lithofacies are grouped into lithofacies associations (or belts) that represent sub-environments of a depositional system.
Sixteen thin sections were prepared from representative samples of the lithofacies associations in order to characterize the main features (sedimentary structure, texture, fabric, primary and diagenetic composition) (Fig. 2). In exception, the sampling of conglomerates not represent the heterogeneous composition observed in the entire layer. Since they present normal grading that command the grain size and composition variations. The thin sections were impregnated with blue dyed epoxy and stained with a solution of Alizarin Red S and potassium ferricyanide to distinguish the carbonate species (Dickson, 1965). Qualitative petrography analysis was performed using a Zeiss AXIO Imager 2 microscope and the photomicrographs were taken using the ZEN 2012 program. The modal composition of arenites was qualitatively measured with comparative visual charts and was plotted in a first order diagram following the concepts of Zuffa (1980) to define which samples are siliciclastic, hybrid or carbonates. The carbonate samples were classified according to Dunham (1962) and Embry and Klovan (1971).

Stromatolites analysis was made in macro-, meso and micro-scale (Hofmann, 1973; Awramik, 1991). Field description was based on chart of stromatolites structures proposed by Preiss (1976). Petrological descriptions were applied to define a detailed genetic classification for stromatolites and thrombolites (Riding, 2011).

\section{Lithofacies}

Eleven lithofacies were recognized for the studied interval (Table 1; Figs. 3 and 4). The carbonate-siliciclastic compositions of the lithofacies were determined by qualitative petrographic descriptions. Compositional mixing is present in all lilthological groups, with slightly variable siliciclastic/carbonate concentrations. Siliciclastic grains occur as: (i) nuclei for oolites; (ii) particles trapped by microorganisms; (iii) free in the rock fabric; (iv) constituent of intraclasts (Fig. 3). The lithofacies are represented by three different compositions: (i) stromatolites; (ii) hybrid arenites; (iii) intraformational hybrid conglomerates and rudstones. The main petrographic characteristics of each lithology are detailed below.

\subsection{Stromatolites}

The stromatolites are represented by two lithofacies: bioherms (STb) and horizontally laminated stromatolites (STh) (non-columnar stromatolites sensu Preiss, 1976). They both have carbonate-siliciclastic compositions and similar textures in optical microscopy, being better distinguished by macroscopical morphology, as can be seen in the lithofacies description (Table 1).

The horizontally laminated stromatolites (Fig. 3A and B) are formed by millimetric to centimetric laminations composed mainly of carbonate peloids (coalescing to form a clotted texture), siliciclastics, hybrid and carbonate intraclasts (oolitic - peloidal grainstones and dolomitized mudstones), and rare carbonate ooids. Together with sparry crust (Fig. 3B), these laminations create incipient columnar forms, within which clotted micrite ghosts are locally present. The siliciclastic phases are comprised of monocrystalline quartz, microcline, orthoclase, rare undifferentiated rock fragments (low-grade metamorphic rocks or chert), tourmaline, muscovite and epidote. Stylolites generally develop where the siliciclastic content is relatively high (Fig. 3B) and bordering the sparry crusts. The main diagenetic processes include overgrowth of continuous and discontinuous quartz and K-feldspar, replacement of ooids and carbonate intraclasts by microcrystalline silica, pervasive dolomitization modifying primary and diagenetic constituents, as well as the cementation of intergranular pores and replacement of heavy minerals by diagenetic titanium oxides. According to Dunham (1962) and Embry and Klovan (1971), these stromatolites can be classified as boundstones. According to Riding (2011), the horizontal stromatolites can be classified as sparry crust with grains. In contrast to horizontal stromatolites, the bioherms present a pervasive replacement of primary phases by dolomite and microcrystalline silica, obliterating the original fabric. Parallel and wavy lamina (Fig. 3C and D), delineated by 

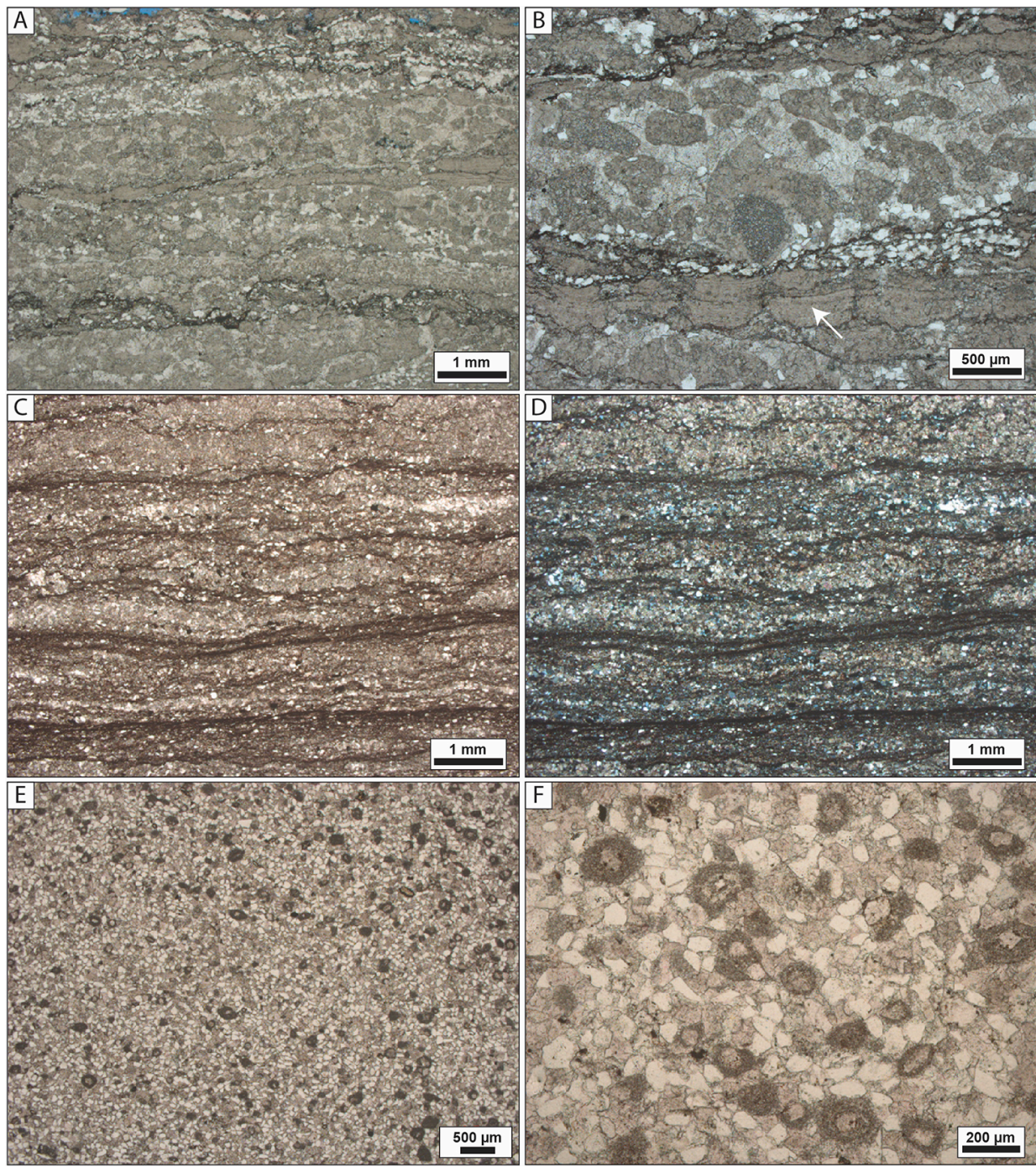

Fig. 3. Textural characteristics, primary constituents and diagenetic aspects of the main lithological groups. (A) Laminations composed by segregated levels of carbonate peloids, ooids, hybrid and carbonate intraclasts, siliciclastics and sparry crusts in the horizontal stromatolites. (B) Sparry crust (arrow) is overlap by a subsequent siliciclastic level with stylolites. Carbonate intraclasts and peloids are concentrated in levels with minor dispersed siliciclastic content. (C - D) Parallel and wavy laminations preserved in the bioherms. (E) Very fine to fine-grained hybrid arenites, moderated sorted, composed mainly by quartz, feldspar and carbonate ooids. (F) Slightly deformed carbonate ooids are replaced by microcrystalline dolomite. Siliciclastic grains are partially replaced by macrocrystalline dolomite in the hybrid arenites. (G) Incipient horizontal lamination is marked by carbonate and hybrid intraclasts orientation in the oolitic hybrid arenites. (H) Discontinuous quartz overgrowths covering detrital quartz grains (arrow) are common. Siliciclastic and carbonate grains are intensely replaced by blocky dolomite (dol) and microcrystalline silica (ms). (I) and (J) Sparry crust and micritic intraclasts, carbonate ooids and siliciclastics are the main components of hybrid conglomerates and intraclastic rudstone. Siliciclastic grains also occur as ooid nucleus (arrow). (K) and (L) Granules and pebbles of oolitic, micritic and hybrid intraclasts, and carbonate ooids are the main components in the hybrid conglomerates and intraclastic rudstone. Sub-rounded siliciclastic grains (mainly quartz and feldspars) occur dispersed in the fabric and inside the intraclasts. All photomicrographs are taken in parallel-polarized light, except D and $\mathrm{H}$. horizontal stylolites and associated sulfides, are composed by siliciclastic (quartz, orthoclase, microcline and muscovite) and undifferentiated constituents intensely replaced by dolomite.

\subsection{Hybrid arenites}

The hybrid arenites comprise the Sm, Sl, St, Sr, Sscs, Shcs and Sw lithofacies. The arenites are very fine- to fine-grained (Fig. 3E, F, G and $\mathrm{H}$ ), moderately to poorly-sorted, with a grain-supported texture and a normal packing pattern. The visualization of the original roundness of the siliciclastics (subangular to subrounded) is hindered by the continuous and discontinuous quartz and K-feldspar overgrowths (Fig. $3 \mathrm{H}$ ). The primary constituents are composed of carbonate ooid (with quartz as nuclei) and peloids, carbonate and hybrid intraclasts, monocrystalline quartz, orthoclase, microcline and plagioclase. In contrast, heavy minerals such as tourmaline, monazite, epidote, rutile, staurolite, zircon and titanite, and undifferentiated rock fragments (chert and low-grade metamorphic rocks) are rare in the analyzed samples. The proportion of primary constituents varies from 30 to $70 \%$ of siliciclastics when compared to carbonate particles. According to Zuffa (1980), these percentages allow to classify the samples as hybrid arenites. The main diagenetic processes are the overgrowth of quartz and K-feldspar, pervasive dolomitization and later silicification that replaces the primary constituents and fills the primary and secondary porosity (Fig. $3 \mathrm{H}$ ).
Selective dissolution in the ooids, horizontal discontinuous stylolites with blocky pyrite and titanium diagenetic mineral replacing heavy minerals are rare.

\subsection{Intraformational hybrid conglomerates and rudstones}

The intraformational hybrid conglomerates and rudstones compose the Gm and Gt lithofacies (Fig. 3I, J, K and L). These lithotypes are very poorly sorted, with grain- to cement-supported textures and highly variable composition, ranging from 2 to $60 \%$ of siliciclastics compared to carbonate sediments. In some samples, the dominance of carbonate and hybrid intraclasts does not represent the heterogeneous composition observed in the entire layer. The intraclasts range in size from very coarse sand to pebble, rounded, and compositionally consist of oolitic grainstones, laminated or massive hybrid arenites, sparry crust and microbial in texture. Sometimes, the intraclasts are fractured, replaced by dolomite and/or bordered by stylolites. The arenaceous portion of the conglomerates are composed of mono- and polycrystalline quartz, orthoclase, microcline, plagioclase, chert fragments, rutile, zircon, tourmaline, monazite, epidote, biotite, and carbonate ooid and peloid. The siliciclastic grains are very fine- to fine-grained and subangular to subrounded. As in the case of the hybrid arenites, continuous and discontinuous quartz and K-feldspar overgrowths make it difficult to visualize the original roundness of the grains. Carbonate ooids (Fig. 3J) 

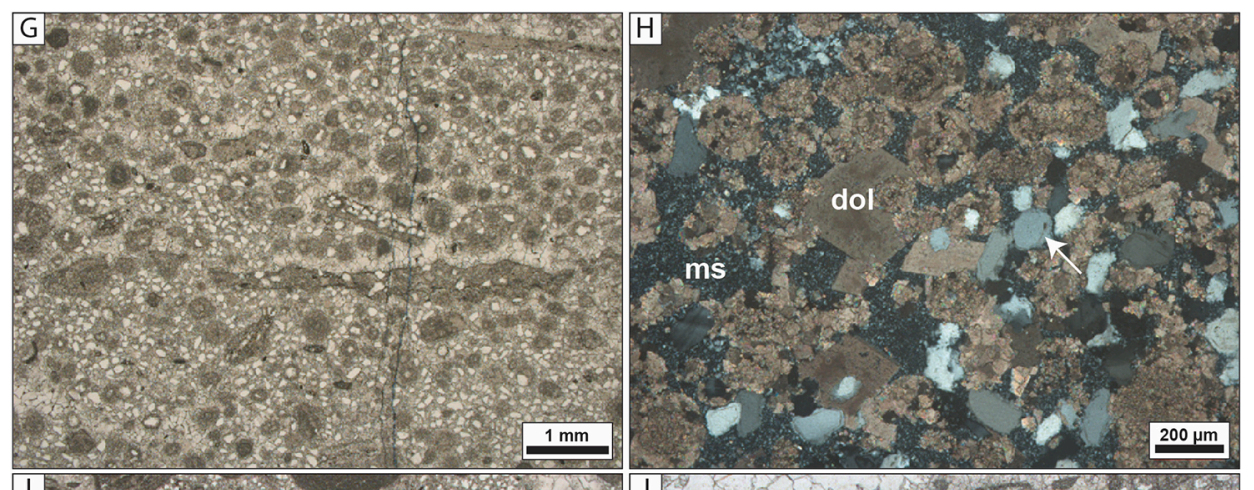

Fig. 3. (continued).
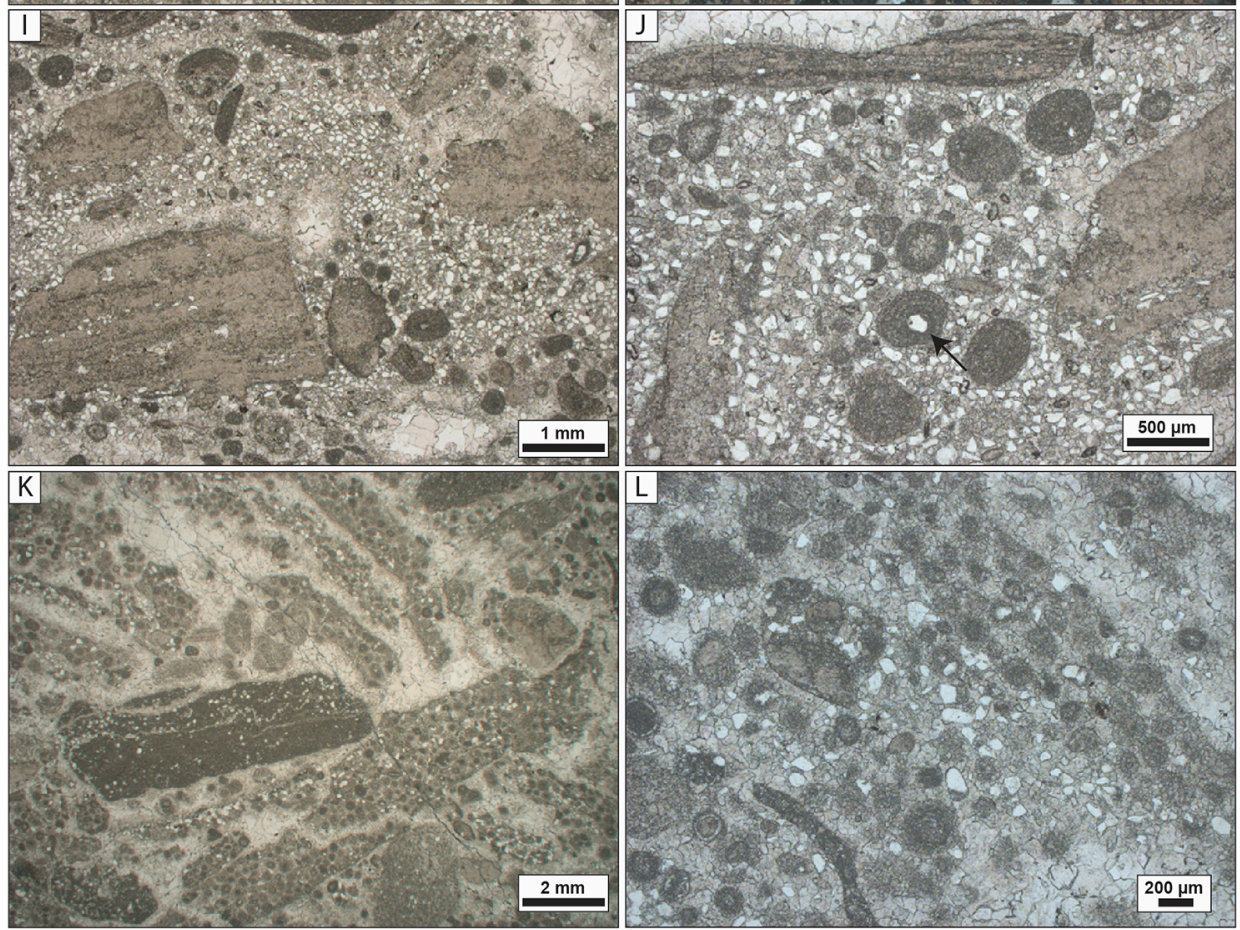

and peloids are fine to medium-grained in size, intensely recrystallized and replaced by dolomite.

The diagenetic processes and products are very similar to the hybrid arenites, consisting of quartz and K-feldspar overgrowths, intense dolomitization and silicification that replaced primary and diagenetic constituents and filled pores. Stylolites without preferential orientation is common, bordering carbonate and hybrid intraclasts and being replaced by blocky pyrite.

\section{Lithofacies associations}

The Caboclo Formation in the study area comprises three lithofacies associations identified by distinct proportions between lithofacies (Fig. 5): (1) Offshore; (2) Offshore transition and (3) Shoreface.

\subsection{Offshore}

Facies (Fig. 5) - STh (86\%); Gm (10\%); Sm (3\%); Gt (1\%).

\subsubsection{Description}

This lithofacies association forms tabular packages up to $5 \mathrm{~m}$ thick (Fig. 6A and B). It is composed mainly of horizontally laminated stromatolite (STh), and subordinately of massive hybrid conglomerates $(\mathrm{Gm})$, massive hybrid arenites (Sm) or cross-stratification hybrid conglomerates (Gt). The conglomerates and arenites beds are lenticular and
0.1 to $0.3 \mathrm{~m}$ thick. They intercalate with stromatolites and locally fill small erosive structures (Fig. 6C, D, E and F).

\subsubsection{Interpretation}

The dominant presence of horizontally laminated stromatolites formed by the trapping of very fine to fine-grained siliciclastic particles and sparry crusts with great lateral continuity indicates a low energy condition, probably below the storm-weather wave-base, at a depth corresponding to the offshore (Reading and Collinson, 1996) or the external ramp (Burchette and Wright, 1992). Under fair-weather conditions (Fig. 7A and C), microbial mats dominated the seabed. Proximal areas were occasionally affected by storm waves (Fig. 7B and D) generating resuspension and transport of sediment to the distal portion (Aigner, 1982; Tucker, 1982; Myrow and Southard, 1996; Bádenas and Aurell, 2001; Myrow et al., 2002; Basilici et al., 2012; Pérez-López and Pérez-Valera, 2012; Brady and Bowie, 2017; Collins et al., 2017). Lenticular beds of massive arenites and/or massive conglomerates (Sm and $\mathrm{Gm}$ ) are related to hyperconcentrated gravitational flows (stormgenerated turbidity currents). Besides, storm surge flows carry larger volumes of sediments, generating conglomerates bedforms (Gt) under combined to unidirectional tractive high-velocity flows (Myrow et al., 2002; Brady and Bowie, 2017). The alternation between periods of fairweather and storm events (Fig. 7) resulted in the deposition of different lithofacies in the offshore sub-environment. Horizontally laminated stromatolites accumulated in low-energy periods interspersed with 



Fig. 4. Examples of lithofacies (see Table 1). (A) $\mathrm{Gm}$ - massive hybrid conglomerate with normal gradation; Gt - Trough cross-stratified hybrid conglomerate. (B) Gm - massive hybrid conglomerate; rounded and tabular shaped intraclasts, internally laminated, composing a chaotic fabric. (C) Gt - Trough cross-stratified hybrid conglomerate; stratification marked by the axis orientation of the intraclasts (white lines). (D) Sm - massive hybrid arenite with sparse and chaotic intraclasts. (E) St - two sets of trough cross-stratified hybrid arenite. (F) Sr - Ripple cross-laminated hybrid arenite; note the critical angle of climb. (G) Sl - low angle laminated hybrid arenite; Sw - wave ripple cross-laminated hybrid arenite. (H) Sscs - Swaley cross-stratified hybrid arenite; $\mathrm{Sl}$ - low angle laminated hybrid arenite. (I) Shcs - hummocky crossstratified hybrid arenite. (J) STb - columnar and dome-shaped bioherms. (K) STb - detail of small branched columns composing a bioherm. (L) STb small dome-shaped bioherms with laterally continuous lamination; massive conglomerate filling the inter-bioherms zone and burying them. (M) STh - horizontally laminated stromatolite. Toward the top lamination becomes wavy. (N) STb detail of a small, simple bioherm column; note on the left side of the column the disrupted lamination and the intraclasts. reworked sediments deposited by high-energy storm-induced currents. The absence of sub-aerial exposure features in horizontal stromatolites, such as karstic features and paleosols, is indicative of a permanently submerged area, reinforcing the interpretation of an offshore context.

\subsection{Offshore transition}

Facies (Fig. 5) - STb (31\%); STh (25\%); Sw (14\%); Sm (11\%); Shcs (9\%); Gm (7\%); Gt (2\%).

\subsubsection{Description}

This lithofacies association consists of tabular packages up to $2 \mathrm{~m}$ thick (Figs. 8 and 9). It is composed of bioherms (STb), horizontally laminated stromatolites (STh), hybrid arenites with hummocky cross-stratification (Shcs), wave ripples (Sw) or massive (Sm), massive hybrid conglomerates $(\mathrm{Gm})$ and with trough cross-stratification $(\mathrm{Gt})$. Arenite beds with wave ripple lamination usually occurs overlying trough cross-bedded conglomerates or hummocky cross-stratified arenites. Sw lithofacies can also occur intercalated with horizontally laminated stromatolites. Some layers of conglomerates and arenites have great lateral continuity, and can be traced for more than a dozen of meters.

Bioherms are exclusive to this lithofacies association, making up columns and domes from 0.1 to $1.3 \mathrm{~m}$ thick and lateral extension $<3 \mathrm{~m}$, which are built from horizontally laminated stromatolite pavement. Morphologically they are simple domes with laterally continuous lamination or with more complex shapes composed of branched or notbranched columnar structures. Internally to bioherms, concentration of intraclasts are common (Fig. 8F). The bioherms occur as isolated constructions (Fig. 8G) or as laterally connected domes, wich are built from the same depositional horizon (Fig. 8B, C, D and E). The interdome areas were filled by hybrid conglomerates ( $\mathrm{Gm}$ and $\mathrm{Gt}$ ) and/or arenites (Sw, Sm and Shcs) separated by millimetric or centimetric levels of horizontal stromatolites (STh). In some cases, horizontal stromatolites are eroded, forming millimetric levels of microbial intraclasts at the base of arenites 



Fig. 4. (continued). and conglomerates. Typically, arenites and conglomerates fill the interbioherms depressions zone, burying the stromatolite buildups and flattening the relief (Fig. 8B, C, D and E).

\subsubsection{Interpretation}

This lithofacies association is typical of a context in which rapid and intense variations in energy occur in the system. This alternation of energetic periods suggests that these deposits were formed in the offshore transition (Dott and Bourgeois, 1982; Reading and Collinson, 1996) or middle ramp (Burchette and Wright, 1992), between the fairweather wave-base and the storm-weather wave-base.

Hybrid arenites and conglomerates were deposited by storm-related flows. The aggradational, isotropic to anisotropic hummocky arenite beds (Shcs) are related to oscillatory to combined flow, while trough cross-stratified conglomerates (Gt) are deposited as a result of strong unidirectional currents developed during storm events (Dott and Bourgeois, 1982; Molina et al., 1997; Dumas and Arnott, 2006; Chen, 2014). The massive hybrid conglomerates and arenites deposits ( $\mathrm{Gm}$ and Sm respectively) are related to hyperconcentrated gravitational flows, interpreted as storm-generated turbidity currents (Aigner, 1982; Myrow and Southard, 1996; Bádenas and Aurell, 2001; Myrow et al., 2002; Brady and Bowie, 2017).

The arenites with wave ripples cross-lamination (Sw) overlying trough cross-stratified conglomerates (Gt) and hummocky arenite (Shcs) deposits represent the attenuation of the intensity of the storm. The storm's peak energy generates unidirectional or combined flows, resuspending sandy sediments, rip-up and transporting clasts from the (semi)consolidated substrate, generating erosive surfaces. The decrease in storm intensity results in pure oscillatory to slightly combined flows, initially depositing Gt or Shcs followed by Sw, representing the waning flow stage of a storm (Collins et al., 2017).

The development of bioherms responds to the dynamics of shallow marine depositional processes, growing in a context of relatively high water depth and moderate to high wave energy (Andres and Reid, 2006). In the present case, the bioherms were established over a hardground formed by horizontal stromatolites developed during relatively long fair-weather periods (Fig. 10A and B). During storm events (Fig. 10C and E), the oscillatory flows and storm-induced currents shape the stromatolitic morphology and increase the grain availability to be trapped by the microbial colony (Logan et al., 1964; Gebelein, 1969; Hofmann, 1973; Walter, 1977; Grotzinger and Knoll, 1999; Andres and Reid, 2006; Dupraz et al., 2006). The relief between the bioherms was filled during storm events until the sedimentation rate exceeds the microbial accretion rate, burying the bioconstructions (Fig. 10E). The burial of bioherms can occur by a single storm event or by the stacking of multiples events. In cases of multi-events (Fig. 10), periods of fairweather are recorded by the development of thin levels of horizontally laminated stromatolites, which separate layers of hybrid arenites and 


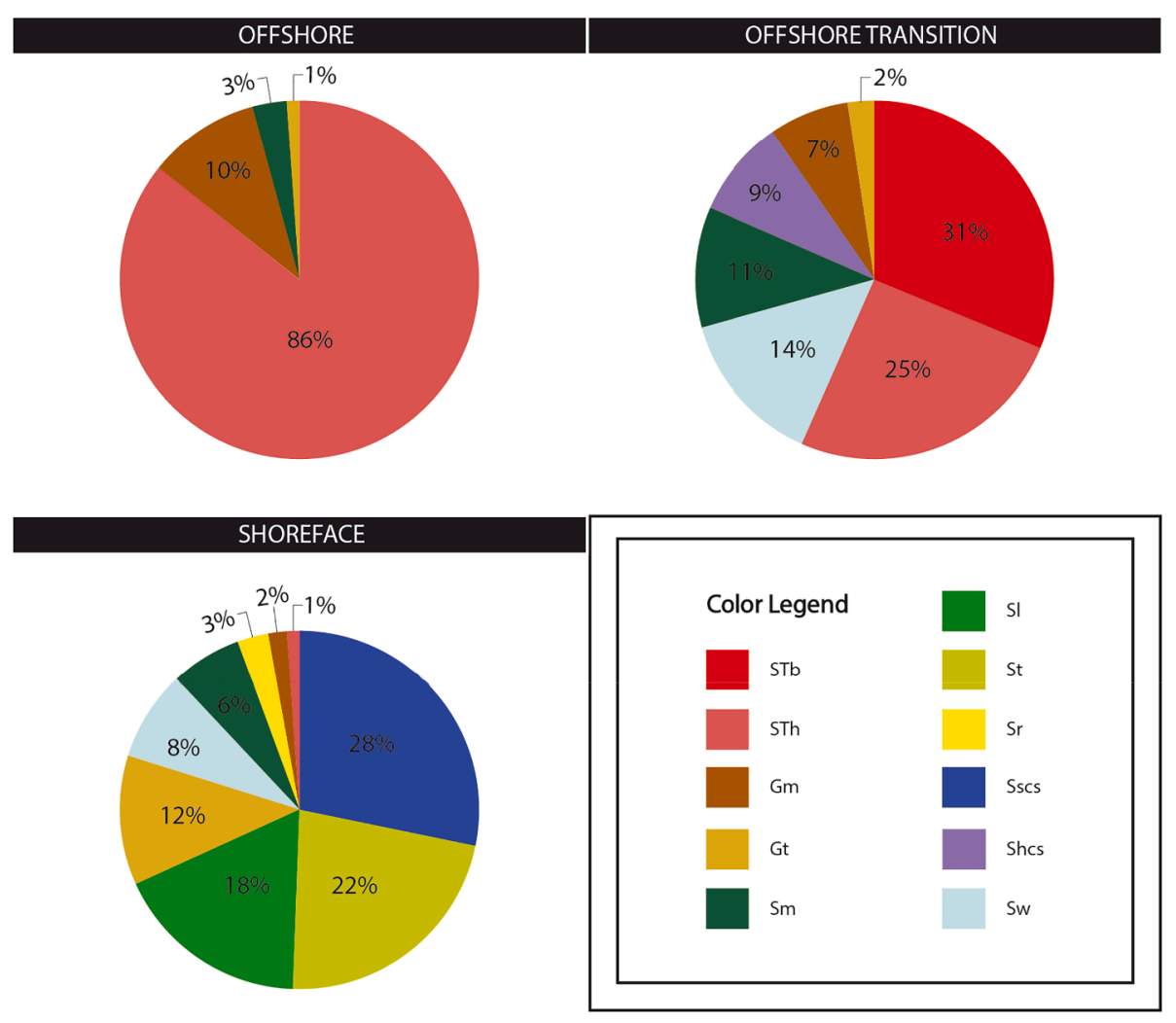

Fig. 5. Diagrams showing the percentage of lithofacies in each lithofacies association.

conglomerates deposited during storm events (Shcs, Sw, Sm, Gm and Gt). STh layers were often eroded during the early stages of storm events, leaving only intraclastic lags. These multiple events are recorded in the bioherms as internal erosive surfaces covered by clastic sediments and intraclasts added to the colony and by the disruption and deformation of the laminations.

When the storms were very intense and/or frequent, there was no time and conditions to establish a stable substrate through the early cementation of microbial mats (hardground), and consequently, bioherms do not form. Therefore, in these periods, the offshore transition was formed by the high-frequency intercalations of hybrid arenites, conglomerates and thin layers of horizontally laminated stromatolite (Fig. 9). The presence of STh layers with maximum thickness of $0.15 \mathrm{~m}$ suggests periods of a few years between storm events (Dibenedetto and Grotzinger, 2005). The occurrence of bioherms could also be linked to open or sheltered areas on the coast. In sheltered portions, the intensity with which storms hit the coast was lower compared to open areas. This energy difference could result in offshore transition sheltered zones with bioherms and open areas without bioherms coexisting laterally.

\subsection{Shoreface}

Facies (Fig. 5) - Sscs (28\%); St (22\%); Sl (18\%); Gt (12\%); Sw (8\%); Sm (6\%); Sr (3\%); Gm (2\%); STh (1\%).

\subsubsection{Description}

This lithofacies association forms tabular packages up to $2 \mathrm{~m}$ thick (Fig. 11), composed of amalgamated sets ( $<0.3 \mathrm{~m}$ thick) of hybrid arenites with through cross-stratification (St), low angle cross-stratification (Sl), swaley cross-stratification (Sscs), wave ripples (Sw) and, less frequently, current ripples (Sr). Massive hybrid arenites and conglomerates ( $\mathrm{Sm}$ and $\mathrm{Gm}$ ) are subordinated, and in most cases, it is possible to identify an indistinct lamination (faint lamination). Horizontally laminated stromatolites (STh), up to $4 \mathrm{~cm}$ thick, can occur interlayered with hybrid arenites and conglomerate lithofacies (Fig. 11D and E). However, stromatolitic levels may have been partially or totally eroded, being incorporated as intraclasts at the base of the overlapping layers of arenites and conglomerates.

\subsubsection{Interpretation}

The occurrence of amalgamated arenite beds composed mainly of oscillatory and combined flows structures suggests a high energy shoreface or inner ramp environment, above the fair-weather wave-base (Dott and Bourgeois, 1982; Burchette and Wright, 1992; Reading and Collinson, 1996). Swaley cross-stratification arenites (Sscs) are related to storm-generated combined flows in nearshore areas (Dumas and Arnott, 2006). However, relatively permanent subcritical to supercritical unidirectional currents occured in the surf zone, forming subaqueous dunes (St and Sl) probably associated to rip or longshore currents (Fig. 12A and C) (Dott and Bourgeois, 1982; Leckie and Walker, 1982). In periods of low energy, microbial carpets colonized the seabed. According to Bose et al. (2012), microbial mats can develop in short periods of time (8-12 h), probably linked to intervals of low intensity of fair-whether waves (Fig. 12B and D). Increasing the intensity of fairwhether waves or during storm events these microbial deposits could be partially or totally eroded.

\section{Stratigraphyc cycles}

A large-scale transgressive-regressive cycle was identified in the Caboclo Formation in the study area (TR - Johnson and Murphy, 1984; Catuneanu et al., 2009), which is characterized by a retrogradational stacking pattern at the base and a progradational stacking pattern to the top (Fig. 2). The retrogradational trend is represented by an upward increase in the proportion of lithologic packages of offshore transition and offshore lithofacies associations relative to the shoreface lithofacies associations; whereas, the reverse trend occurs in the progradational part. The maximum flooding surface (MFS - Posamentier and Vail, 1988) 

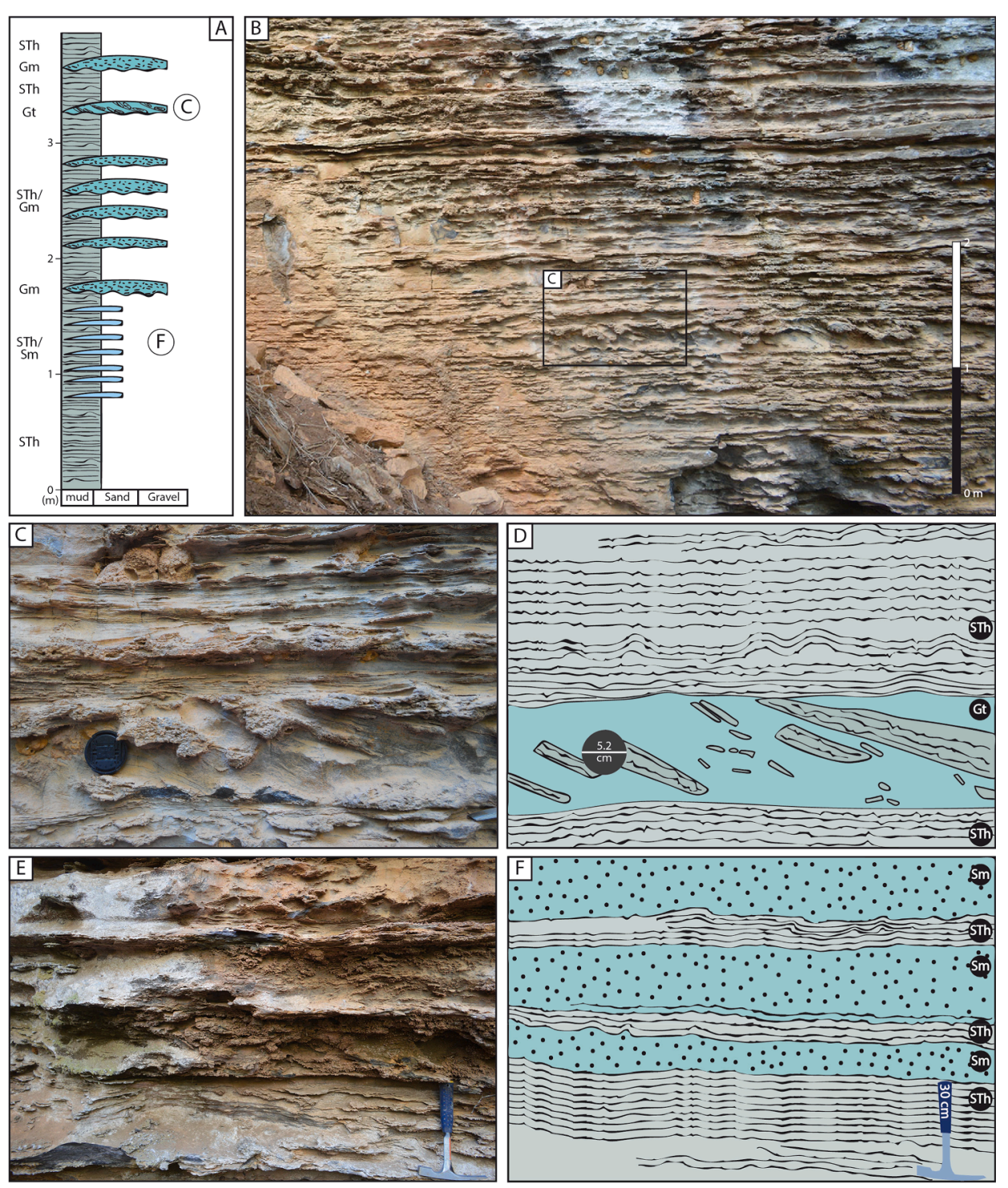

Fig. 6. (A) Typical stacking pattern of the offshore lithofacies association. (B) Outcrop showing the stacking of offshore layers; note the lateral continuity of the STh layers and the lenticular geometry of the arenites and conglomerates. (C - D) Photograph and interpretation of an interval in which occurs the overlap of horizontally laminated stromatolites (STh) with small domes, and trough cross-stratified conglomerate (Gt). (E - F) Photograph and interpretation showing the overlap of horizontally laminated stromatolites (STh) and massive arenites (Sm). is marked by a 3-meter-thick aggradational interval that consists essentially of offshore deposits. Although the precise position of MFS is not defined, the interval display the inversion of retrogradational to progradational stacking pattern.

In the $\log$ section intervals between 0 and $9.5 \mathrm{~m}$ and $25-34 \mathrm{~m}$ (Fig. 2), the large T-R cycle can be subdivided into 10 high-frequency meter-scale cycles. The high-frequency sequences are composed essentially by progradational asymmetrical cycles, with gradual or abrupt stacking of lithofacies and bounded by maximum regression surfaces (MRS). In this study, the MRS are consistently defined as those that represent an abrupt flooding, marked by a vertical shift of lithofacies associations from shoreface to offshore or offshore transition and from offshore transition to offshore. In cases in which progradational cycles are stacked, the MFS coincides with the MRS. Eight of the ten highfrequency sequences record a gradual lithofacies successions, consisting of 1 to $3 \mathrm{~m}$ thick cycles characterized by the overlying of laterally adjacent lithofacies associations. Two complete cycle record the shallowing from offshore to shoreface. However, incomplete cycles showing vertical transition from offshore transition to shoreface or offshore to offshore transition may also occur. Two high-frequence sequences, up to $1.5 \mathrm{~m}$ thick, document abrupt lithofacies successions. These cycles are composed by the overlying of lithofacies associations that are not laterally adjacent, passing sharply from offshore to shoreface deposits, without the offshore transition deposits between them.

The presence of different scales of transgressive-regressive cycles in the Caboclo Formation indicates that, similarly to the Phanerozoic, the Proterozoic record is also organized in different stratigraphic orders (Magalhães et al., 2015). The large-scale transgressive-regressive cycle represents long-term variation of the accomodation/sediment supply (A/S) ratio, generating a symmetric sequence with equivalent development of retrogradational and progradational interval. High-frequency cycles respond to high-frequency variations in the A/S ratio (Zecchin, 2007; Catuneanu et al., 2009; Catuneanu and Zecchin, 2013; Magalhães et al., 2015). Gradual, high-frequency progradational sequences occur in periods of relative sea-level rise or stabilization (normal regression), when the $\mathrm{A} / \mathrm{S}$ ratio is positive, between 0 and 1 . Incomplete and abrupt, high-frequency progradational sequences, took place in periods when the coastline regression occurred in response to a drop in relative sea level (forced regression), when $\mathrm{A} / \mathrm{S}$ ratio $<0$. The asymmetric anatomy of the cycles, essentially composed of regressive intervals, indicates a low-gradient topography of the Caboclo ramp associated with the relatively low sedimentary supply during transgressive phases (Cattaneo and Steel, 2003; Zecchin, 2007; Catuneanu and Zecchin, 2013). This interpretation based on the anatomy of the cycles is compatible with the depositional model of the mixed storm-dominated ramp proposed for the Caboclo Formation, which will be discussed in detail in Section 7.2. 


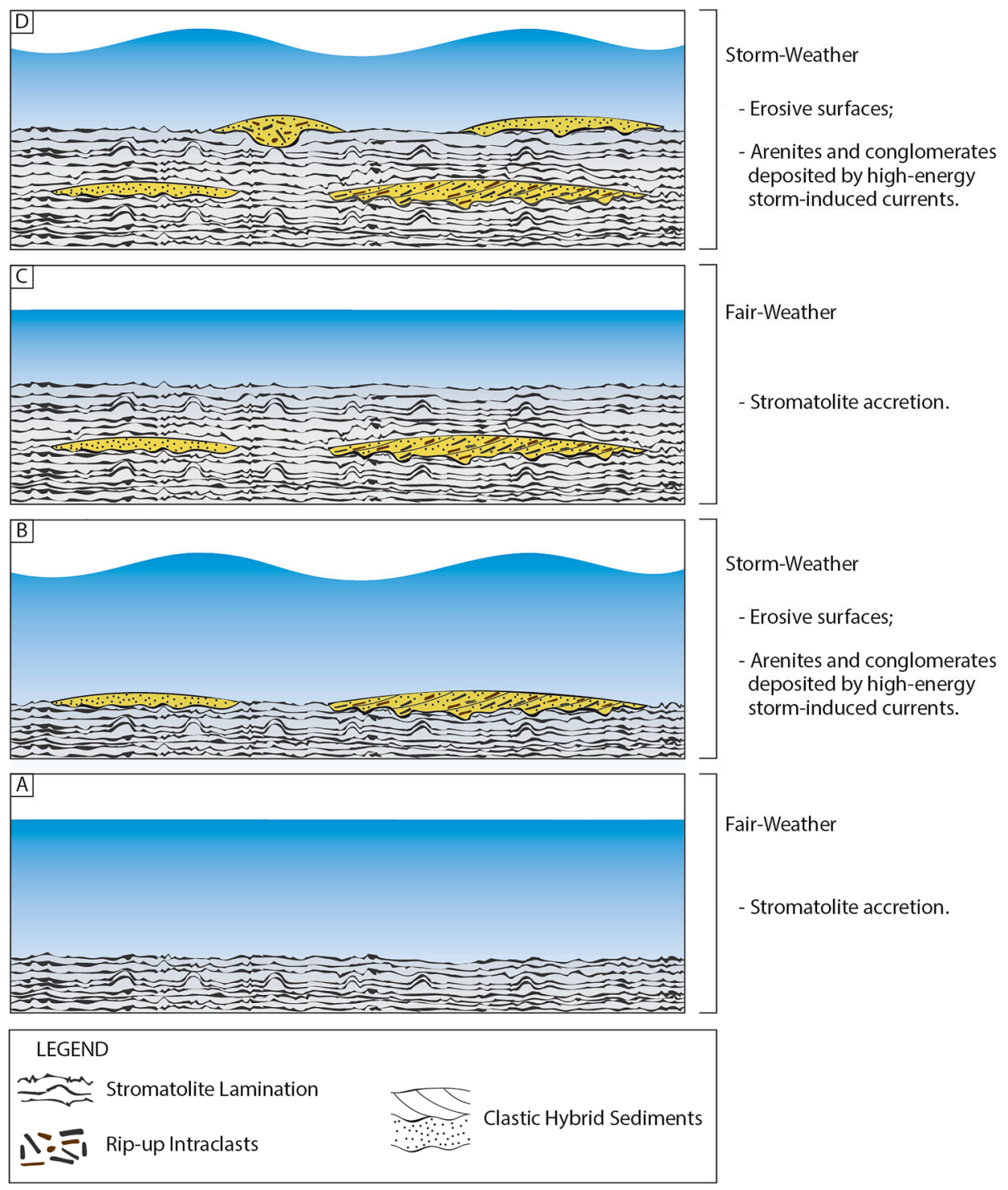

Fig. 7. Successions of events (A to D) showing the alternation of fair- and storm-weather periods and its associated deposits in the offshore zone.

\section{Discussion}

\subsection{Carbonate-Siliciclastic mixing}

The hybrid deposits of the Caboclo Formation present compositional mixing that occurs in all layers, with slightly variable siliciclastic/carbonate concentrations. Siliciclastic sediments occur as: (i) nuclei for oolites; (ii) particles trapped by microorganisms; (iii) free in the rock fabric; (iv) constituent of intraclasts (Fig. 3). The persistent and homogeneous composition of the sediments indicates that the terrigenous input was relatively constant and that the carbonate precipitation occurred simultaneously or almost simultaneously with the continental input. Faciological analysis (Fig. 2 and Table 1) suggests fair-weather waves and storm events as the dominant processes during deposition.

The lack of records of continental and coastal deposits does not allow the construction of the precise source of the siliciclastic sedimentary supply to the basin. However, sedimentological features (sorting and roundness of terrigenous grains) allow some inferences about the supply of terrigenous sediments (Folk and Ward, 1957; Flemming, 2007, 2017). The siliciclastic grains are well-sorted and sub-angular to rounded (Fig. 3), indicating selective transport and reworking during long distances. These characteristics suggest a sedimentary supply from terminal portions of alluvial systems. Siliciclastic input can be linked to transport processes in storm periods. Through these events, two mechanisms can contribute to the terrigenous sediment input: (i) alluvial and (ii) storm-surge ebb. During storms, alluvial systems would have higher discharge, increasing the sedimentary supply at the river mouth along the coastline. In addition, with the increase in the coastal setup, the siliciclastic sediments accumulated in the river mouths were reworked and transported to offshore zones.

During fair-weather periods, siliciclastic grains served as nuclei for the formation of ooids and oncoids, under moderate and constant action of normal waves. During storms, these allochems were mixed with new siliciclastic sediments added to the shoreface, generating hybrid deposits by the mixture of siliciclastic and carbonate grains. It is important to observe that in the studied deposits the size of siliciclastic grains is always one or two granulometric classes smaller than the carbonate allochems. These deposits with different grain sizes, under the same hydrodynamic regime, can be explained by the difference in the density of the particles (Allen, 1984; Flemming, 2017; Garzanti, 2017). In the hybrid arenites from the Caboclo Formation, the grain size difference is promoted by the difference in density between the denser siliciclastic sediments with silt to fine sand size and less denser, fine to coarse sand size carbonate ooids and oncoids. The lower density of the carbonate 

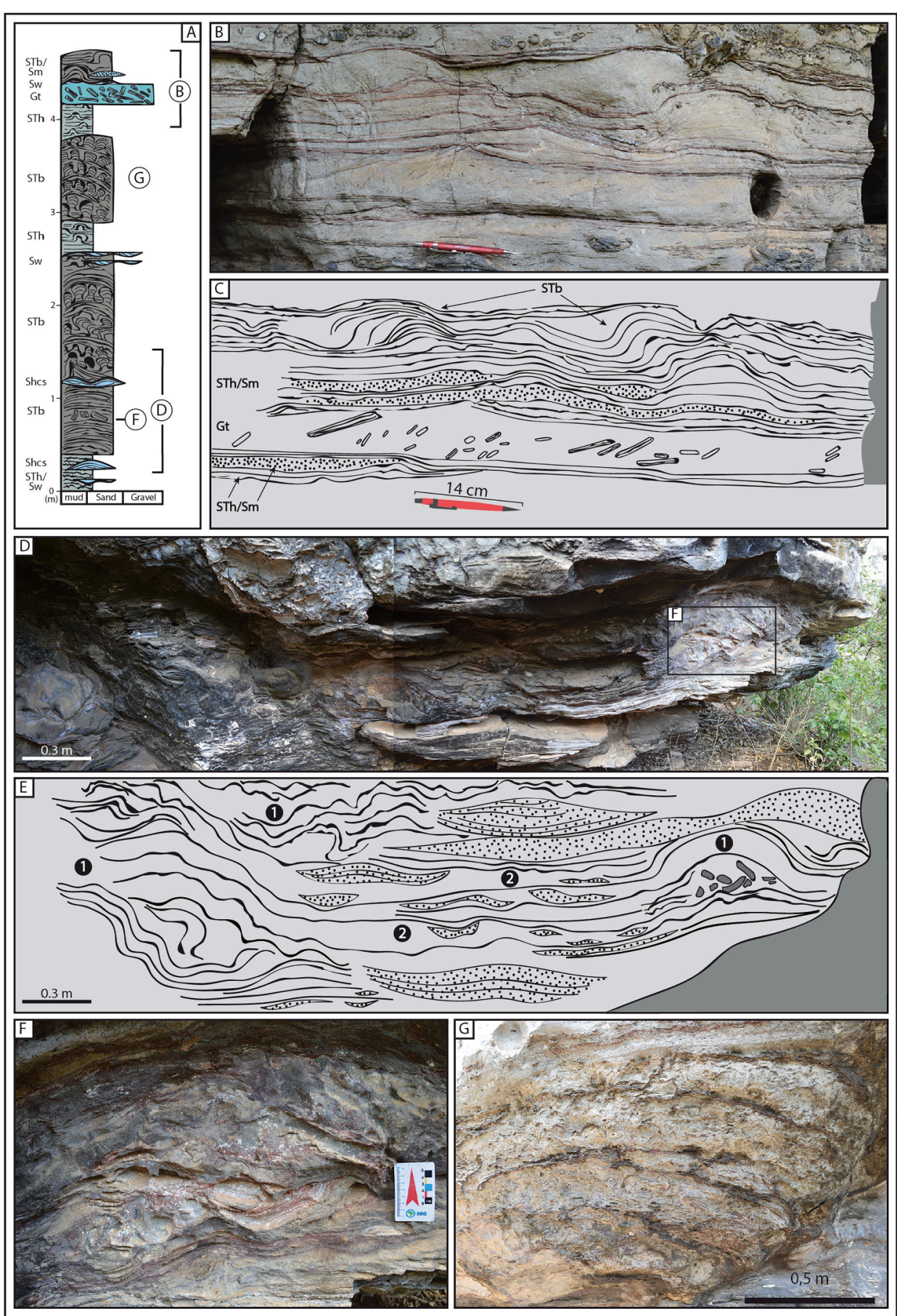

Fig. 8. (A) Typical stacking pattern of the offshore transition with bioherms. (B - C) Photograph and interpretation. Interval with overlap of trough cross-stratified conglomerate (Gt), horizontally laminated stromatolites (STh), massive arenites (Sm) and bioherms (STb). The lateral transition of detrital and microbial lithofacies indicates contemporaneous deposition between them. (D - E) Photograph and interpretation. Bioherms (STb - 1) and the space between them (2) filled by horizontally laminated stromatolites (STh) and arenites (dotted layers) with wave ripples (Sw) and hummocky crossstratification (Shcs). (F) Detail of the concentration of intraclasts within a bioherm. (G) Isolated dome-shaped bioherm. sediments is linked to their microporosity (Flügel, 2004; Hashim and Kaczmarek, 2019). According to Sellwood and Beckett (1991), microporosity within ooids can vary from $30 \%$ (pristine radial) to $50 \%$ (micritized). This caused the deposition of coarser carbonate particles together with finer siliciclastic grains. A clear grain-size segregation is recorded only with the gravel fraction (intraclasts), which presents a significantly larger weight than the siliciclastic, ooid and oncoid grains, concentrating at the base of the normally-graded beds. This does not apply to sediments deposited by non-selective processes (i.e. hyperconcentrated flows), in which grain segregation cannot occur.

\subsection{Depositional model}

The absence of rimmed shelves deposits (e.g., carbonate sand shoal or reefs and fore-reef talus) and the well-defined offshore, offshore transition and shoreface lithofacies associations, indicates that the studied interval can be interpreted as a very low-gradient ramp with carbonate-siliciclastic sedimentation (Fig. 13). The offshore distal areas are represented mainly by horizontally laminated stromatolites (Figs. 6 and 7). Offshore transition deposits are characterized by the presence of bioherms and horizontal stromatolites intercalated with hybrid lithofacies generated by the action of storm waves (Figs. 8, 9 and 10). In turn, the shoreface portion consists of amalgamated hybrid arenites, with combined flow structures, intercalated with thin and discontinuous 


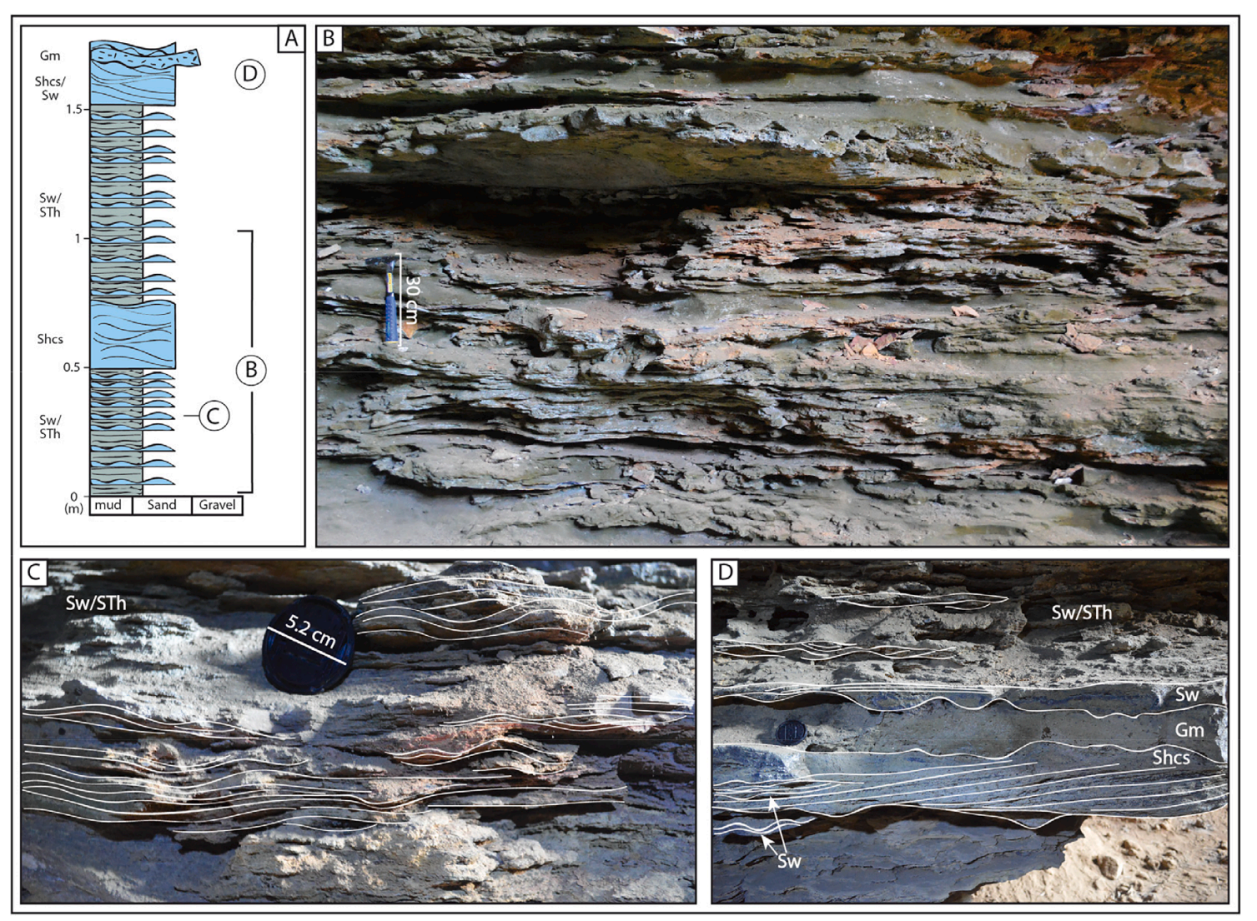

Fig. 9. (A) Stacking pattern of the offshore transition without the developmento of bioherms. (B) Outcrop showing the stacking of offshore transition deposits; note the abrupt transition of a highfrequence intercalation of small wave ripples (Sw) and horizontally laminated stromatolites (STh) to a hummocky (Shcs). (C) Detail of the high-frequency intercalations of wave ripples cross-laminated arenite (Sw - white lines) and horizontally laminated stromatolites (STh). (D) Anisotropic hummocky cross-stratification arenite (Shcs) transitioning laterally to wave ripples arenites (Sw) and overlapped by massive conglomerate $(\mathrm{Gm})$ with wave ripples (Sw) on the top. Sw/STh - High-frequency intercalations of wave ripples cross-laminated arenite and horizontally laminated stromatolites.

layers of horizontal stromatolites (Figs. 11 and 12). This faciological distribution indicates a storm-dominated carbonate-siliciclastic ramp, with wide microbial colonization from shallow to relatively deep waters (below storm-wave base level).

The ramp morphology of the Caboclo Formation is the result of the balance between the growth and development of stromatolites and the input and distribution of sediments. Stromatolites growth generates morphological differences of the substrate, forming millimetric roughness at lamina scale and bioherms at macro-scale. In both situations, these irregularities are smoothed due to the high rate of sediment mobility induced by normal and storm waves, redistributing the sediments along the coast. The intense wave actions inhibit the development of a platform edge and prevent the ramp from evolving into a rimmed shelf (Dibenedetto and Grotzinger, 2005).

Stromatolites occur from the shoreface to the offshore zones of the mixed carbonate-siliciclastic Caboclo ramp (Fig. 13). The wide distribution and abundance of stromatolites seems to be a feature of the Precambrian (Hofmann, 1973; Knoll and Semikhatov, 1998; Grotzinger and Knoll, 1999; Grotzinger and James, 2000; Riding, 2000; Allwood et al., 2006). The occurrence of stromatolitic deposits of the Caboclo Formation is similar to the Early Proterozoic stromatolitic carbonate platform of Campbellrand subgroup (Beukes, 1987), the Lower Proterozoic Pethei Group carbonate platform (Hoffman, 1974) and the 2.72 Ga stromatolite biofacies of Tumbiana Formation (Coffey et al., 2013). In these units stromatolitic deposits form thick successions $(1,500 \mathrm{~m}$ in Campbellrand Subgroup; $350 \mathrm{~m}$ in Pethei Group) across the entire carbonate platform, from shallower to deeper waters environments. In the Phanerozoic, stromatolites had a more restricted living environment, were less abundant and had less diversity of morphological types (Yancey, 1991; Gomez and Astini, 2015; Brady and Bowie, 2017). Modern stromatolites are present in extreme environments (i.e., springs, hotsprings, hypersaline lagoons, alkaline lakes). Exuma Cays in Bahamas is the only current example analogous to the Precambrian coast stromatolites, whereas they are restricted to a proximal narrow belt of the platform (Reid et al., 1995; Reid et al., 2000, 2003; Dupraz et al., 2009; Reid et al., 2011; Bowlin et al., 2012).

The large microbial amount and wide distribution observed in Caboclo Formation (Fig. 13), as well as in other Proterozoic successions, can be linked to two interconnected factors: (i) detrital mud and (ii) predators. The absence of mud reduces water turbidity and increases the luminosity, generating optimal conditions for the substrate colonization by microbial even in relatively deep waters. In addition, microbes were the only life in the middle Proterozoic, with no predators that could inhibit the development of microbial colonies, allowing the stromatolite to occur in different depositional zones of the ramp, as long as there was mineral matter and enough light for photosynthesis (Hofmann, 1973; Walter, 1977; Awramik, 1991; Riding, 2000, 2011).

The characteristic morphologies of stromatolites present in each lithofacies association in the detailed section of the Caboclo Formation are controlled by specific physical parameters (water column, currents e.g., Logan et al., 1964; Walter, 1977; Andres and Reid, 2006; Dupraz et al., 2006; Varejão et al., 2019). In offshore low-energy distal areas, microbial mats spread laterally over large distances with little or no interference from currents (Fig. 7). In the offshore transition, the morphology of the bioherms is shaped by currents induced by waves (Fig. 10). In times of low energy microbial carpets were established, while during storm events these carpets were disrupted and moulded for tens to hundreds of years, forming isolated buildings. In turn, the constant wave energy on the shoreface inhibits the formation of stromatolites, restricting their occurrence to thin layers of microbial carpets, which in most cases were broken, being incorporated as intraclasts in arenites and conglomerates (Fig. 12).

\subsection{Compositional homogeneity in stratigraphic succession}

Mixed carbonate-siliciclastic ramp models indicate variations in the degree of mixing in facies scale or on specific facies associations, coexisting laterally with purely carbonate or siliciclastic deposits (e.g., Mount, 1984; Sanders and Höfling, 2000; Chiarella et al., 2017; Gomez and Astini, 2015; Labaj and Pratt, 2016; Schwarz et al., 2018). This variation in the degree of mixing reflects a set of controlling factors related to the processes responsible for the production and deposition of carbonate grains and to the processes linked to the input of siliciclastic sediments. These processes are variable not only in the dip direction, but also in the strike direction, generating depositional models with different trends of spatial distribution of facies (Coffey and Sunde, 2014; Labaj and Pratt, 2016; 


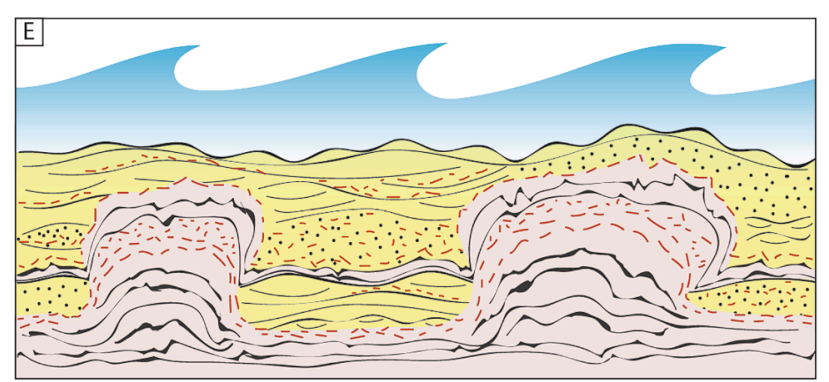

D
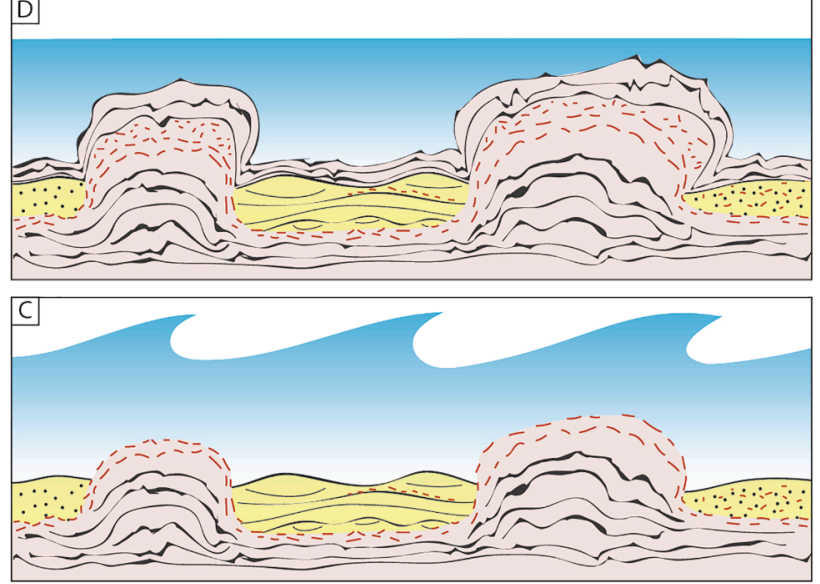

B

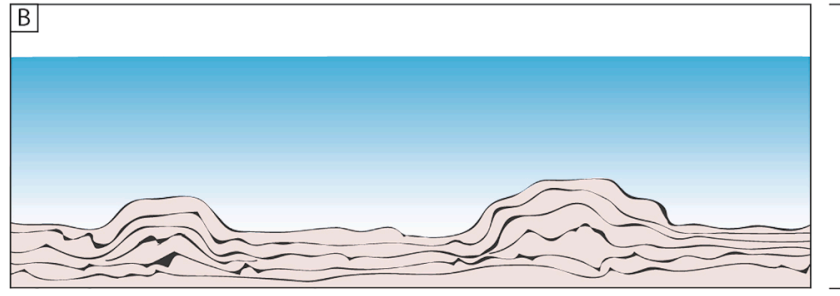

A
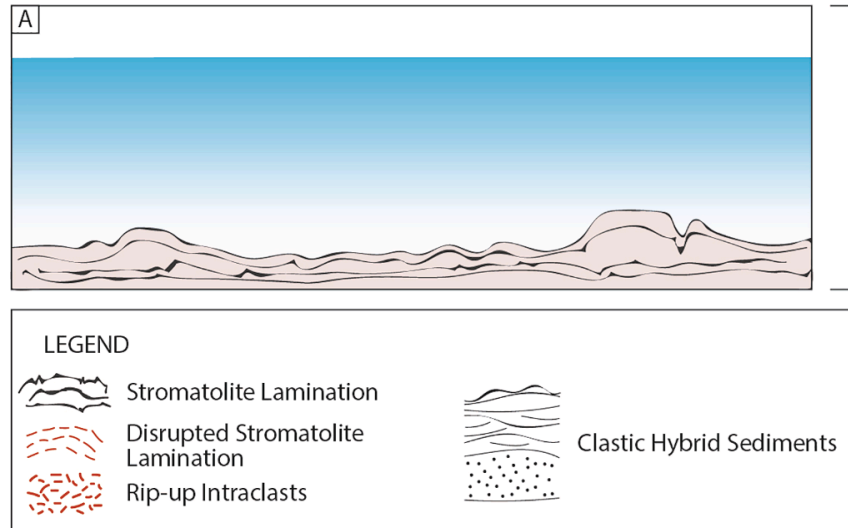

Storm-Weather

- Disruption and erosion of stromatolite lamination;

- Intraclasts rip-up and incorporated to storm deposits;

- Arenites and conglomerates deposits between bioherms;

- Bioherms totally buried.

Fair-Weather

- Stromatolite accretion;

- Intraclasts incorporation in stromatolite lamination;

- Stromatolite lamination capping clastic hybrid sediments between bioherms;

Storm-Weather

- Disruption and erosion of stromatolite lamination;

- Intraclasts rip-up and incorporated to storm deposits;

Arenites and conglomerates deposits between bioherms.

Fair-Weather

Beginning of construction of small bioherms.

Fair-Weather

- Stable substrate and hardground formation.

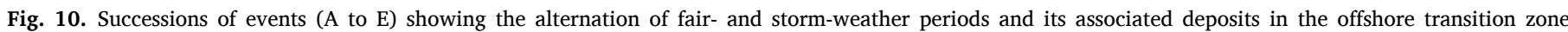
with bioherms.

Schwarz et al., 2016, 2018). The Caboclo Formation in the study area differs from other recent and ancient carbonate-siliciclastic ramps, being characterized by the homogeneity of hybrid deposits throughout the stratigraphic succession (Fig. 2). This compositional homogeneity is linked to the wide distribution an regularity of the siliciclastic input during the sedimentary accumulation. That is, during the interval studied the Caboclo Formation coastal region is characterized by wide alluvial plain with multiple poins of sedimentary input that allowed a homogeneous distribution of sandy siliciclastic sediments. During storms there is an increasing in fluvial discharge and, consequently, in sediment load transported to the coast. In addition, strong currents induced by storms allow the transport and mixing of siliciclastic sediments stored in the river mouth bars with carbonate grains generated in the basin during fairweather periods. The very limited presence of silt and clay particles allowed carbonate production was not interrupted in different sectors of the ramp. That is, a high sedimentary supply, mobility and distribution of siliciclastic sandy sediments on a ramp with contemporary carbonate production generates the indiscriminate mixture of sediments, making the deposit homogeneously hybrid.

\section{Conclusions}

- Eleven lithofacies are grouped in three lithofacies associations: offshore, offshore transition and shoreface. All lithofacies are 


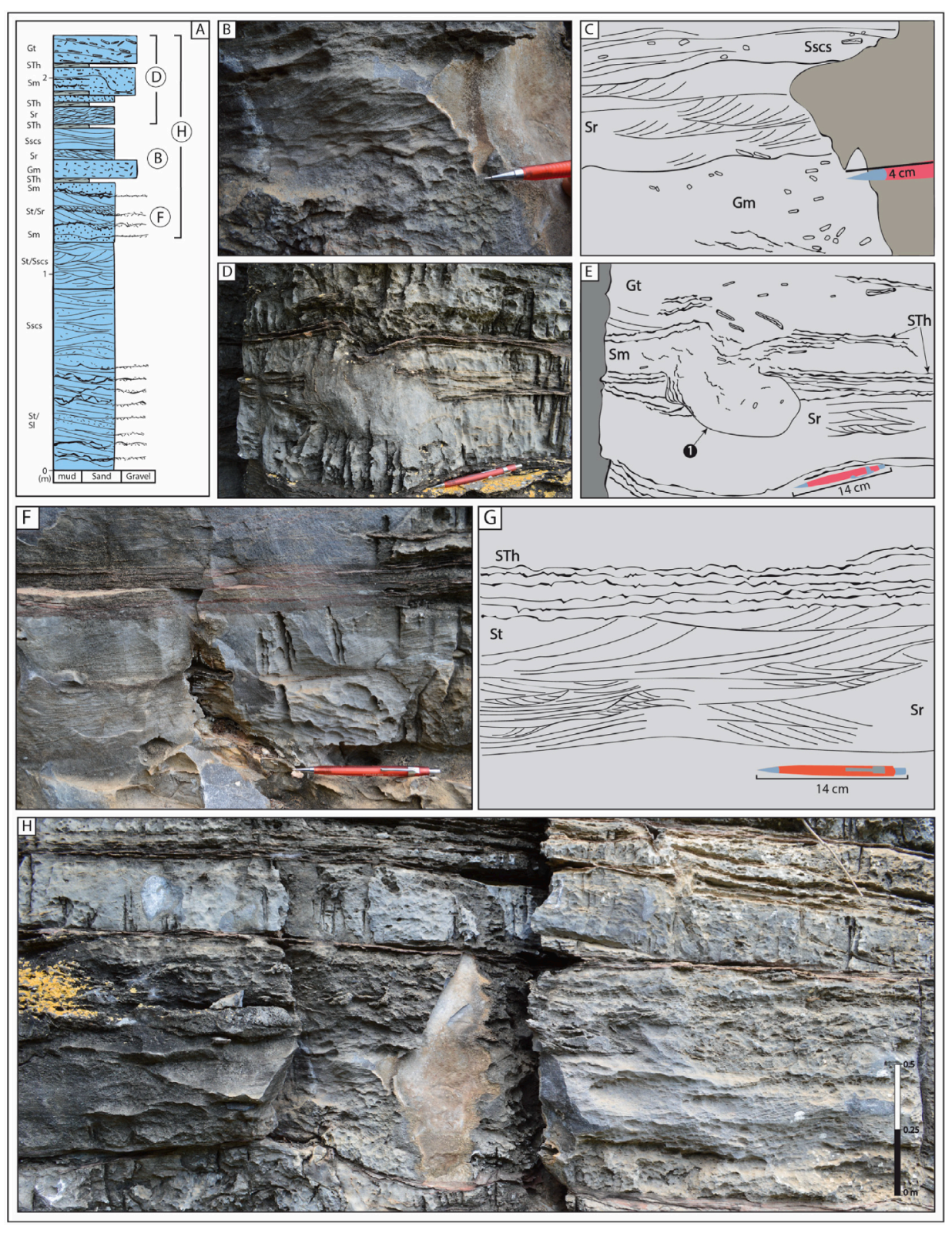

Fig. 11. (A) Typical stacking pattern of the shoreface lithofacies association. (B - C) Photograph and interpretation of an interval with overlapping of massive conglomerate $(\mathrm{Gm})$, ripples cross-lamination arenite (Sr) and swaley cross-stratification arenites (Sscs). Note the irregular contact between lithofacies, and the change in the agle of climb of the ripples (Sr) from subcritical to critical. (D - E) Photograph and interpretation of an interval with ripple crosslamination arenite (Sr), horizontally laminated stromatolites (STh), massive arenites (Sm) and trough cross-stratified conglomerate (Gt). Erosive structure (1) filled with massive arenite. (F - G) Ripple cross-lamination arenite (Sr) passing upward to trough cross-stratification arenite (St). Horizontally laminated stromatolite (STh). (H) Interval showing shoreface stacking layers. 


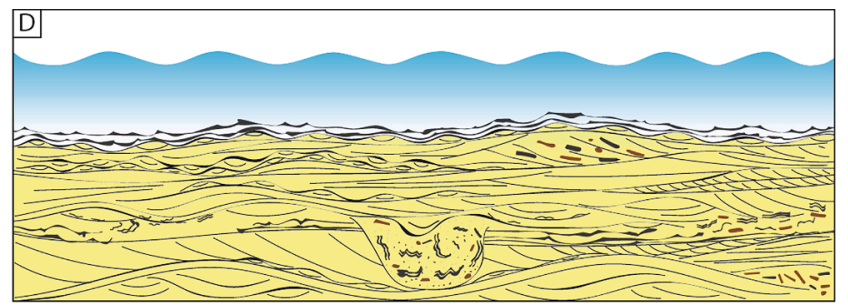

Low intensity of fair-weather (normal) waves

- Stable substrate and

development of microbial mat;

- Hardground formation;

- Very thin layers of sandstones.

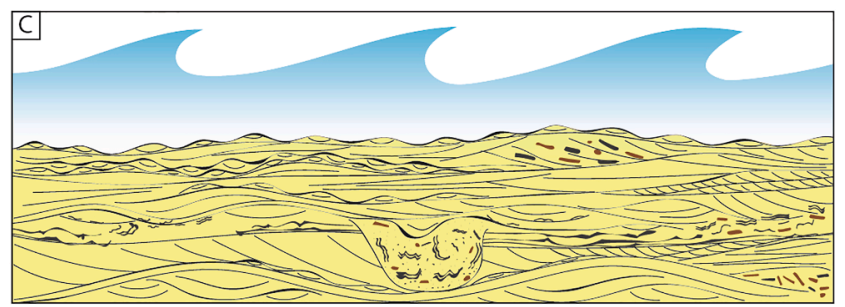

Storm- and Fair-Weather waves

- Erosive structures;

- Disruption of microbial mats and rip-up intraclasts;

- Arenites and conglomerates with oscillatory and combined structures.

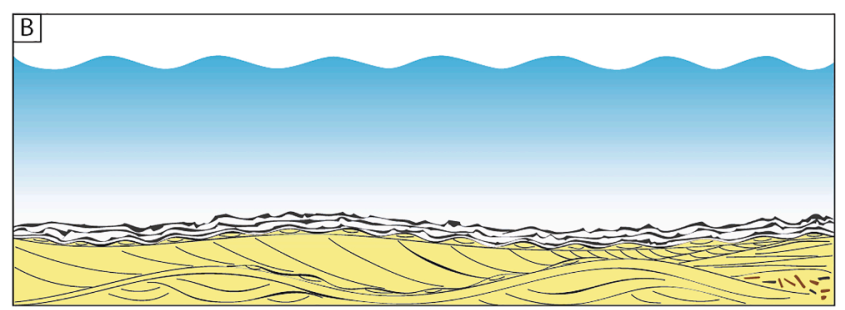

Low intensity of fair-weather (normal) waves

- Stable substrate and development of microbial mat;

- Hardground formation;

- Very thin layers of sandstones.

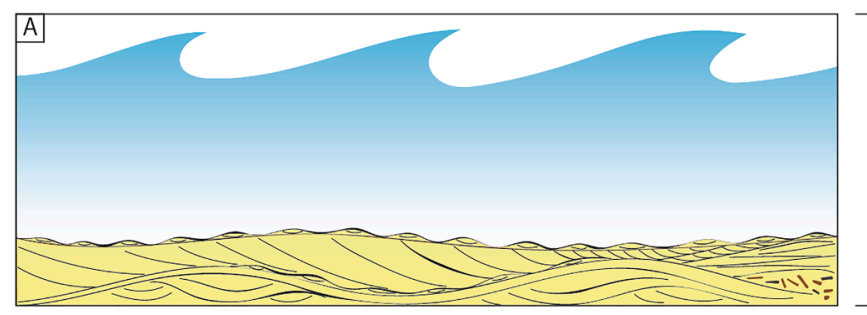

Storm- and Fair-Weather waves

Arenites and conglomerates with oscillatory and combined structures.

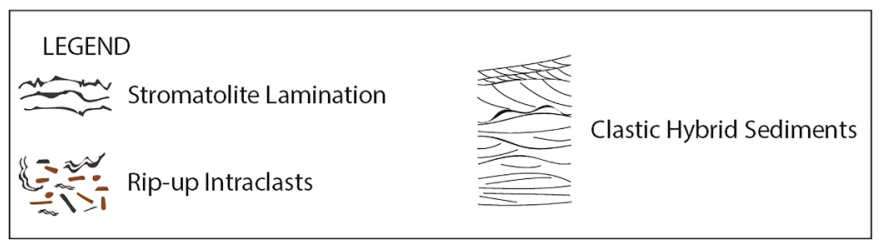

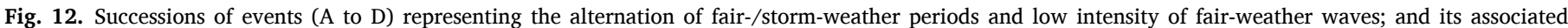
deposits in the shoreface zone. 

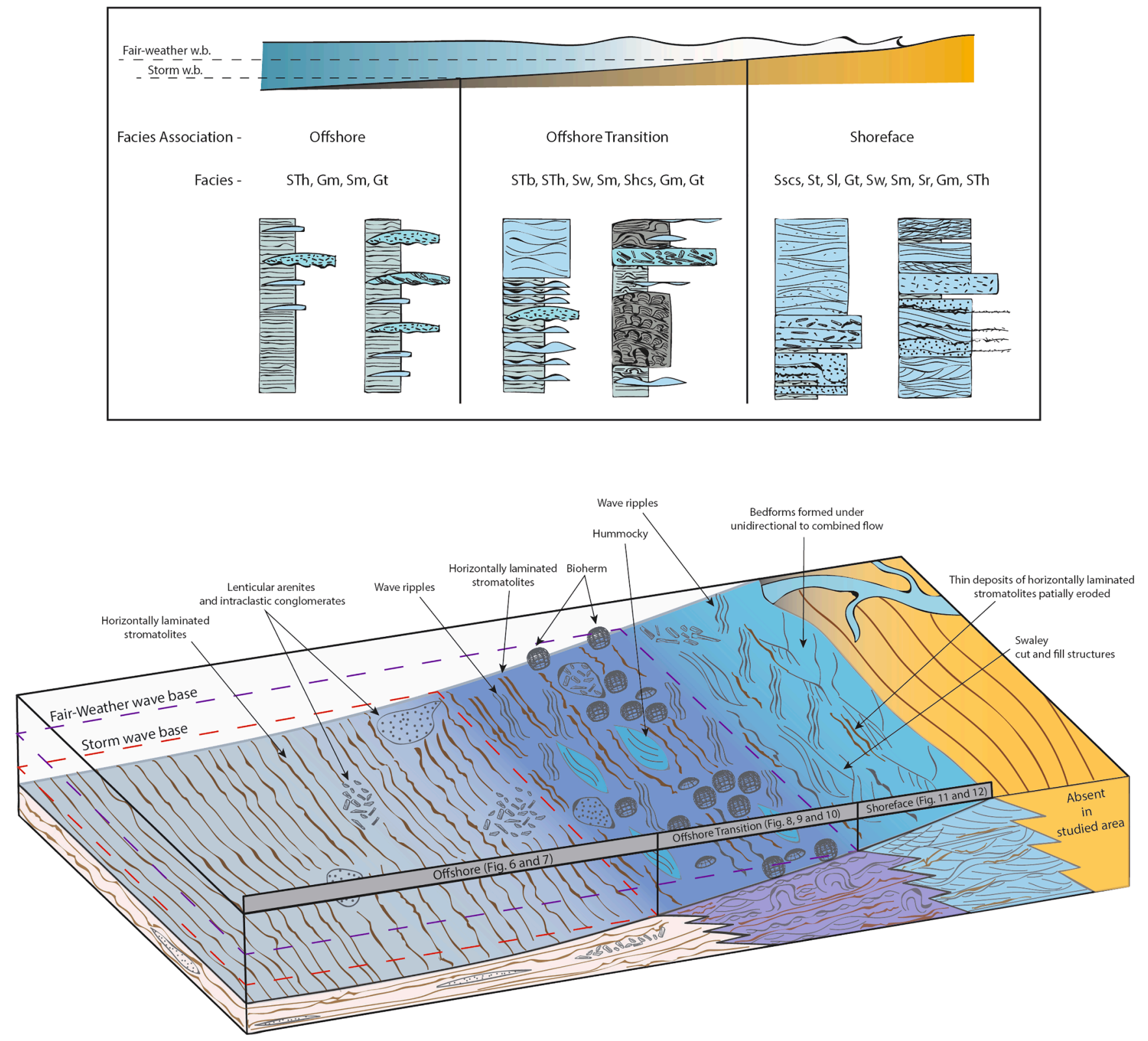

Fig. 13. Distribution of lithofacies and lithofacies associations for the bathymetric profile and the storm and fair-weather wave base limits.

compositionally carbonate-siliciclastic and stromatolites occur in all lithofacies associations.

- The faciological analysis indicates a low gradient carbonatesiliciclastic ramp dominated by the action of normal and storm waves, with wide microbial colonization from shallow to relatively deep waters environments.

- The siliciclastic input does not inhibit the carbonate precipitation. The terrigenous input and the carbonate precipitation occurred simultaneously or almost simultaneously.

- The large microbial amount and wide distribution is associated with the absence of detrital mud and the absence of predators. The absence of mud would have reduced the turbidity of water column and increased the luminosity, generating optimal conditions for the substrate colonization even in the deepest portions of the system. In addition, the absence of predators would have allowed the stromatolite to occur in different depositional zones of the ramp without competition.

\section{Declaration of Competing Interest}

The authors declare that they have no known competing financial interests or personal relationships that could have appeared to influence the work reported in this paper.

\section{Acknowledgments}

This paper is part of the $\mathrm{PhD}$ thesis carried out by the first author at the Universidade Federal do Rio Grande do Sul (UFRGS) and fully sponsored by Petrobras. JPFF thank Francisco Barbosa for the assistance, dedication and friendship during the fieldwork. L. F. De Ros and G. K. L. Orita are acknowledged for their helpful with the petrographic analysis and constructive comments. The authors thank the editor Professor Wilson Teixeira, and the constructive comments made by Giorgio Basilici and an anonymous reviewer. 


\section{References}

Aigner, T., 1982. Calcareous tempestites: storm-dominated stratification in Upper Muschelkalk limestones (Middle Trias, SW-Germany). In: Einsele, G., Seilacher, A. (Eds.), Cyclic and event stratification. Springer-Verlag, Heidelberg, Heidelberg, pp. 180-198.

Alkmim, F.F., Martins-Neto, M.A., 2012. Proterozoic first-order sedimentary sequences of the São Francisco craton, eastern Brazil. Mar. Pet. Geol. 33, 127-139.

Allen, J.R.L., 1984. Wrinkle marks: an intertidal sedimentary structure due to aseismic soft-sediment loading. Sed. Geol. 41, 75-95.

Allwood, A.C., Walter, M.R., Kamber, B.S., Marshall, C.P., Burch, I.W., 2006. Stromatolite reef from the Early Archean of Australia. Nature 441, 714-718.

Andres, M.S., Reid, R.P., 2006. Growth morphologies of modern marine stromatolites: a case study from Highborne Cay, Bahamas. Sed. Geol. 185, 319-328.

Awramik, S.M., Riding, R., 1988. Role of algal eukaryotes in subtidal columnar stromatolite formation. Proceeding of National Academy of Science, USA 85, 1327-1329.

Awramik, S.M., 1991. Archaean and Proterozoic stromatolites. In: Riding, R. (Ed.), Calcareous algae and stromatolites. Springer-Verlag, Heidelberg, pp. 289-304.

Babinski, M., Van Schmus, W.R., Chemale Jr, F., Brito Neves, B.B., Rocha, A.J.D., 1993. Idade isocrônica $\mathrm{Pb} / \mathrm{Pb}$ em rochas carbonáticas da Formação Caboclo, em Morro do Chapéu, BA. Simpósio sobre o Cráton do São Francisco 2, 160-163.

Bádenas, B., Aurell, M., 2001. Proximal-distal facies relationships and sedimentary processes in a storm dominated carbonate ramp (Kimmeridgian, northwest of the Iberian Ranges, Spain). Sed. Geol. 139, 319-340.

Barnaby, R.J., Ward, W.B., 2007. Outcrop analog for mixed siliciclastic-carbonate ramp reservoirs - stratigraphic hierarchy, facies architecture, and geologic heterogeneity: Grayburg Formation, Permian Basin, USA. J. Sediment. Res. 77, 34-58.

Basilici, G., de Luca, P.H.V., Poiré, D.G., 2012. Hummocky cross-stratification-like structures and combined-flow ripples in the Punta Negra Formation (Lower-Middle Devonian, Argentine Precordillera): a turbiditic deep-water or storm-dominated prodelta inner-shelf system? Sed. Geol. 267, 73-92.

Beukes, N.J., 1987. Facies relations, depositional environments and diagenesis in a major early Proterozoic stromatolitic carbonate platform to basinal sequence, Campbellrand Subgroup, Transvaal Supergroup, Southern Africa. Sed. Geol. 54, $1-46$.

Bose, P.K., Eriksson, P.G., Sarkar, S., Wright, D.T., Samanta, P., Mukhopadhyuay, S., Mandal, S., Banerjee, S., Altermann, W., 2012. Sedimentation patterns during the Precambrian: a unique record? Marine Petroleum Geology 33, 34-68.

Bowlin, E.M., Klaus, J.S., Foster, J.S., Andres, M.S., Custals, L., Reid, R.P., 2012. Environmental controls on microbial community cycling in modern marine stromatolites. Sed. Geol. 263, 45-55.

Brady, M., Bowie, C., 2017. Discontinuity surfaces and microfacies in a storm-dominated shallow Epeiric Sea, Devonian Cedar Valley Group, Iowa. The Depositional Record 3 , $136-160$.

Branner, J.C., 1910. The Tombador Escarpment in the State of Bahia, Brazil. Am. J. Sci. 30, 335-343.

Brito Neves, B.B., Kawashita, K., Delhal, J., 1979. A evolução geocronológica da Cordilheira do Espinhaço; dados novos e integração. Revista Brasileira de Geociências 9, 71-85.

Brito Neves, B.B., Campos Neto, M.D.C., Fuck, R.A., 1999. From Rodinia to Western Gondwana: an approach to the Brasiliano-Pan African Cycle and orogenic collage. Episodes-Newsmagazine of the International Union of Geological Sciences 22 155-166.

Burchette, T.P., Wright, V.P., 1992. Carbonate ramp depositional systems. Sedimentary geology 79, 3-57.

Campos Neto, M.C., 2000. Orogenic systems from southwester Gondwana. In: Cordani, U.G., Milani, E.J Thomaz Filho, A., Campos, D.A. (Eds.), Tectonic Evolution of South America, 31th International Geological Congress. Rio de Janeiro, Brasil, pp. 335365.

Cattaneo, A., Steel, R.J., 2003. Transgressive deposits: a review of their variability. Earth Sci. Rev. 62, 187-228.

Catuneanu, O., Zecchin, M., 2013. High-resolution sequence stratigraphy of clastic shelves II: controls on sequence development. Mar. Pet. Geol. 39, 26-38.

Catuneanu, O., Abreu, V., Bhattacharya, J.P., Blum, M.D., Dalrymple, R.W., Eriksson, P. G., Fielding, C.R., Fisher, W.L., Galloway, W.E., Gibling, M.R., Giles, K.A., Holbrook, J.M., Jordan, R., Kendall, C.G., St, C., Macurda, B., Martinsen, O.J., Miall, A.D., Neal, J.E., Nummedal, D., Pomar, L., Posamentier, H.W., Pratt, B.R., Sarg, J.F., Shanley, K.W., Steel, R.J., Strasser, A., Tucker, M.E., Winker, C., 2009 Towards the standardization of sequence stratigraphy. Earth Sci. Rev. 92, 1-33.

Chemale Jr., F., Alkmim, F.F., Endo, I., 1993. Late Proterozoic tectonism in the interior of the São Francisco craton. In: Findlay, R.H., Unrug, R., Banks, M.R., Veevers, J.J. (Eds.), Gondwana eight: assembly, evolution and dispersal. Balkema, Rotterdam, pp. 29-41.

Chemale Jr., F., Dussin, I.A., Alkmim, F.F., Martins, M.S., Queiroga, G., Armstrong, R., Santos, M.N., 2012. Unravelling a Proterozoic basin history through detrital zircon geochronology: The case of the Espinhaco Supergroup, Minas Gerais, Brazil. Gondwana Res. 22, 200-206.

Chen, J., 2014. Surface and subsurface reworking by storms on a Cambrian carbonate platform: evidence from limestone breccias and conglomerates. Geologos 20, 13-23.

Chiarella, D., Longhitano, S.G., Tropeano, M., 2017. Types of mixing and heterogeneities in siliciclastic-carbonate sediments. Mar. Pet. Geol. 88, 617-627.

Coffey, J.M., Flannery, D.T., Walter, M.R., George, S.C., 2013. Sedimentology, stratigraphy and geochemistry of a stromatolite biofacies in the $2.72 \mathrm{Ga}$ Tumbiana Formation, Fortescue Group. Western Australia. Precambrian Research 236, 282-296.
Coffey, B.P., Sunde, R.F., 2014. Lithology-based sequence-stratigraphic framework of a mixed carbonate-siliciclastic sucession, Lower Cretaceous, Atlantic coastal plain. AAPG Bull. 98, 1599-1630.

Collins, D.S., Johnson, H.D., Allison, P.A., Guilpain, P., Damit, A.R., 2017. Coupled 'storm-flood'depositional model: Application to the Miocene-Modern Baram Delta Province, north-west Borneo. Sedimentology 64, 1203-1235.

Cruz, S.C., Alkmim, F.F., 2006. The tectonic interaction between the Paramirim aulacogen and the Araçuaí belt, São Francisco craton region, Eastern Brazil. Anais da Academia Brasileira de Ciências 78, 151-173.

Dibenedetto, S., Grotzinger, J., 2005. Geomorphic evolution of a storm-dominated carbonate ramp (c. 549 Ma), Nama Group. Namibia. Geological Magazine 142, 583-604.

Dickson, J.A.D., 1965. A modified staining technique for carbonates in thin section. Nature 205, 587.

Dott Jr, R.H., Bourgeois, J., 1982. Hummocky stratification: significance of its variable bedding sequences. Geol. Soc. Am. Bull. 93, 663-680.

Dumas, S., Arnott, R.W.C., 2006. Origin of hummocky and swaley cross-stratification. The controlling influence of unidirectional current strength and aggradation rate. Geology 34, 1073-1076.

Dunham, R.J., 1962. Classification of carbonate rocks according to depositional texture. In: Ham, W.E. (Ed.), Classification of Carbonate Rocks. American Association of Petroleum Geologists Memoir 1, pp. 108-121.

Dupraz, C., Pattisina, R., Verrecchia, E.P., 2006. Translation of energy into morphology: Simulation of stromatolite morphospace using a stochastic model. Sed. Geol. 185, 185-203.

Dupraz, C., Reid, R.P., Braissant, O., Decho, A.W., Norman, R.S., Visscher, P.T., 2009. Processes of carbonate precipitation in modern microbial mats. Earth Sci. Rev. 96, $141-162$.

Embry, A.F., Klovan, J.E., 1971. A Late Devonian reef tract on Northeastern Banks Island, NWT. Canadian Petroleum Geology Bulletin 19, 730-781.

Flemming, B.W., 2007. The influence of grain-size analysis methods and sediment mixing on curve shape and textural parameters: Implications for sediment trend analysis. Sed. Geol. 202, 425-435.

Flemming, B.W., 2017. Particle shape-controlled sorting and transport behavior of mixed siliciclastic/bioclastic sediments in a mesotidal lagoon, South Africa. Geo-Mar. Lett. 37, 397-410.

Flügel, E., 2004. Microfacies of carbonate rocks, analysis, interpretation and application. Springer Verlag, Berlin, Heidelberg, New York, 976 p.

Folk, R.L., Ward, W.C., 1957. Brazos River bar: a study in the significance of grain size parameters. J. Sediment. Petrol. 27, 3-26.

Frantz, C.M., Petryshyn, V.A., Corsetti, F.A., 2015. Grain trapping by filamentous cyanobacterial and algal mats: implications for stromatolite microfabrics through time. Geobiology 13, 409-423.

Garzanti, E., 2017. The Maturity Myth In Sedimentology and Provenance Analysis. J. Sediment. Res. 87, 353-365.

Gebelein, C.D., 1969. Distribution, morphology, and accretion rate of recent subtidal algal stromatolites, Bermuda. J. Sediment. Res. 39, 49-69.

Gomez, F.J., Astini, R.A., 2015. Sedimentology and sequence stratigraphy from a mixed (carbonate-siliciclastic) rift to passive margin transition: the Early to Middle Cambrian of the Argentine Precordillera. Sed. Geol. 316, 39-61.

Grotzinger, J.P., Knoll, A.H., 1999. Stromatolites in Precambrian carbonates: evolutionary mileposts or environmental dipsticks? Annu. Rev. Earth Planet. Sci. 27, 313-358.

Grotzinger, J.P., James, N.P., 2000. Precambrian carbonates: evolution of understanding. In: Grotzinger, J.P., James, N.P. (Eds.), Carbonate Sedimentation and Diagenesis in the Evolving Precambrian World. SEPM Special Publication 67, pp. 3-20.

Guadagnin, F., Chemale Jr, F., Magalhães, A.J.C., Santana, A., Dussin, I., Takehara, L., 2015. Age constrains on crystal-tuff from the Espinhaco Supergroup - Insight into the Paleoproterozoic to Mesoproterozoic intracratonic basin cycles of the Congo-São Francisco Craton. Gondwana Res. 27, 363-376.

Haines, P.W., 1988. Storm-dominated mixed carbonate/siliciclastic shelf sequence displaying cycles of hummocky cross-stratification, late Proterozoic Wonoka Formation, South Australia. Sed. Geol. 58, 237-254.

Hashim, M.S., Kaczmarek, S.E., 2019. A review of the nature and origin of limestone microporosity. Mar. Pet. Geol. 107, 527-554.

Hoffman, P., 1974. Shallow an deepwater stromatolites in lower Proterozoic platform - to - basin facies change, Great Slave Lake, Canada. The American Association of Petroleum Geologists Bulletin 58, 856-867.

Hofmann, H.J., 1973. Stromatolites: characteristics and utility. Earth Sci. Rev. 9, 339-373.

Johnson, J.G., Murphy, M.A., 1984. Time-rock model for Siluro-Devonian continental shelf, western United States. Geol. Soc. Am. Bull. 95, 1349-1359.

Knoll, A.H., Semikhatov, M.A., 1998. The genesis and time distribution of two distinctive Proterozoic stromatolite microstructures. Palaios 13, 408-422.

Labaj, M.A., Pratt, B.R., 2016. Depositional dynamics in a mixed carbonate-siliciclastic system: Middle-Upper Cambrian Abrigo Formation, southeastern Arizona, USA. J. Sediment. Res. 86, 11-37.

Leckie, D.A., Walker, R.G., 1982. Storm- and tide-dominated shorelines in Cretaceous Moosebar-Lower Gates interval - outcrop equivalents of Deep Basin gas trap in western Canada. AAPG Bull. 66, 138-157.

Logan, B.W., Rezak, R., Ginsburg, R.N., 1964. Classification and environmental significance of algal stromatolites. J. Geol. 72, 68-83.

Magalhães, A.J.C., Raja Gabaglia, G.P., Scherer, C.M.S., Bállico, M.B., Guadagnin, F., Bento Freire, E., Silva Born, L.R., Catuneanu, O., 2015. Sequence hierarchy in a Mesoproterozoic interior sag basin: from basin fill to reservoir scale, the Tombador Formation, Chapada Diamantina Basin, Brazil. Basin Res. 28, 393-432. 
Marshak, S., Alkmim, F.F., 1989. Proterozoic contraction/extension tectonics of the southern São Francisco region, Minas Gerais, Brazil. Tectonics 8, 555-571.

Martins-Neto, M.A., 2000. Tectonics and sedimentation in a paleo/mesoproterozoic riftsag basin (Espinhaço basin, southeastern Brazil). Precambr. Res. 103, 147-173.

Molina, J.M., Ruiz-Ortiz, P.A., Vera, J.A., 1997. Calcareous tempestites in pelagic facies (Jurassic, Betic Cordilleras, southern Spain). Sed. Geol. 109, 95-109.

Mount, J.F., 1984. Mixing of siliciclastic and carbonate sediments in shallow shelf environments. Geology 12, 432-435.

Myrow, P.M., Southard, J.B., 1996. Tempestite deposition. J. Sediment. Res. 66, 875-887.

Myrow, P.M., Fischer, W., Goodge, J.W., 2002. Wave-modified turbidites: combined-flow shoreline and shelf deposits, Cambrian, Antartica. J. Sediment. Res. 72, 641-656.

Pedreira, A.J., 1994. O Supergrupo Espinhaço na Chapada Diamantina centro oriental, Bahia: Sedimentologia, estratigrafia e tectônica. São Paulo, USP, Instituto de Geociências, p. 126.

Pérez-López, A., Pérez-Valera, F., 2012. Tempestite facies models for the epicontinental Triassic carbonates of the Betic Cordillera (southern Spain). Sedimentology 59, 646-678.

Pesonen, L.J., Mertanen, S., Veikkolainen, T., 2012. Paleo-Mesoproterozoic supercontinents - a paleomagnetic view. Geophysica 48, 5-47.

Pisarevsky, S.A., Elming, S.A., Pesonen, L.J., Li, Z.X., 2014. Mesoproterozoic paleogeography: supercontinent and beyond. Precambr. Res. 244, 207-225.

Posamentier, H., Vail, P., 1988. Eustatic controls on clastic deposition, II: sequence and systems tract models. In: Wilgus, C.K., Hastings, B.S., Kendall, C.G.St.C., Posamentier, H.W., Ross, C.A., Van Wagoner, J.C. (Eds.), Sea Level Changes: an Integrated Approach. SEPM Special Publication 42, pp. 125-154.

Preiss, W.V., 1976. Basic field and laboratory methods for the study of stromatolites. In: Walter, M.R. (Ed.), Stromatolites. Developments in Sedimentology, Vol. 20. Elsevier, Amsterdam, pp. 5-13.

Reading, H.G., Collinson, J.D., 1996. Clastic Coasts. In: Reading, H.G. (Ed.), Sedimentary Environments: Processes, Facies and Stratigraphy, 3rd. Edition, pp. 154-231.

Reid, R.P., Macintyre, I.G., Browne, K.M., Steneck, R.S., Miller, T., 1995. Modern Marine Stromatolites in the Exuma Cays, Bahamas: Uncommonly Common. Facies 33, 1-17.

Reid, R.P., Visscher, P.T., Decho, A.W., Stolz, J.F., Bebout, B.M., Dupraz, C., Macintyre, I G., Paerl, H.W., Pinckney, J.L., Prufert-Bebout, L., Steppe, T.F., DesMarais, D.J., 2000. The role of microbes in accretion, lamination and early lithification of modern marine stromatolites. Nature 406, 989-992.

Reid, P., Dupraz, C.D., Visscher, P.T., Sumner, D.Y., 2003. Microbial processes forming marine stromatolites: microbe-mineral interactions with a three-billion-year rock record. In: Krumbein, W.E., Paterson, D.M., Zavarzin, G.A. (Eds.), Fossil and Recent Biofilms - A Natural History of Life on Earth. Springer, Dordrecht, pp. 103-118.

Reid, R.P., Foster, J.S., Radtke, G., Golubic, S., 2011. Modern marine stromatolites of Little Darby Island, Exuma Archipelago, Bahamas: environmental setting, accretion mechanism sand role of euendoliths. In: Reitner, et al. (Ed.), Advances in Stromatolite Geobiology. Lecture Notes in Earth Sciences 131, pp. 77-89.

Riding, R., 1991. Classification of microbial carbonates. In: Riding, R. (Ed.), Calcareous Algae and Stromatolites. Springer-Verlag, Berlin, pp. 21-51.

Riding, R., 2000. Microbial carbonates: the geological record of calcified bacterial-algal mats and biofilms. Sedimentology 47, 179-214.

Riding, R., 2011. Microbialites, stromatolites, and thrombolites. In: Reitner, J., Thiel, V. (Eds.), Encyclopedia of geobiology, Encyclopedia of Earth Sciences Series. Springer, Netherlands, pp. 635-654.
Rocha, A.J., Pereira, C.P., Srivastava, N.K., 1992. Carbonatos da Formação Caboclo (Proterozóico médio) na região de Morro do Chapéu - Estado da Bahia. Revista Brasileira de Geociências 22, 389-398.

Sanders, D., Höfling, R., 2000. Carbonate deposition in mixed siliciclastic-carbonate environments on top of an orogenic wedge (Late Cretaceous, Northern Calcareous Alps, Austria). Sed. Geol. 137, 127-146.

Saylor, B.Z., 2003. Sequence stratigraphy and carbonate-siliciclastic mixing in a terminal Proterozoic foreland basin, Urusis Formation, Nama Group, Namibia. J. Sediment. Res. 73, 264-279.

Scheibner, C., Kuss, J., Speijer, R.P., 2003. Stratigraphic modelling of carbonate platform-to-basin sediments (Maastrichtian to Paleocene) in the Eastern Desert. Egypt. Palaeogeography, Palaeoclimatology, Palaeoecology 200, 163-185.

Schwarz, E., Veiga, G.D., Álvarez Trentini, G., Isla, M.F., Spalletti, L.A., 2018. Expanding the spectrum of shallow-marine, mixed carbonate-siliciclastic systems: Processes, facies distribution and depositional controls of a siliciclastic-dominated example. Sedimentology 65, 1558-1589.

Schwarz, E., Veiga, G.D., Trentini, G.Á., Spalletti, L.A., 2016. Climatically versus eustatically controlled, sediment-supply-driven cycles: Carbonate-siliciclastic, highfrequency sequences in the Valanginian of the Neuquén Basin (Argentina). J. Sediment. Res. 86, 312-335.

Sellwood, B.W., Beckett, D., 1991. Ooid microfabrics: the origin and distribution of high intra-ooid porosity; Mid-Jurassic reservoirs. S. England. Sedimentary Geology 71, 189-193.

Souza, V.H.P., Bezerra, F.H.R., Vieira, L.C., Cazarin, C.L., Brod, J.A., 2021. Hydrothermal silicification confined to stratigraphic layers: Implications for carbonate reservoirs. Mar. Pet. Geol. 124, 104818.

Spalletti, L.A., Franzese, J.R., Matheos, S.D., Schwarz, E., 2000. Sequence stratigraphy of a tidally dominated carbonate-siliciclastic ramp; the Tithonian-Early Berriasian of the Southern Neuquén Basin, Argentina. Journal of the Geological Society 157, 433-446.

Srivastava, N.K., 1988. Estromatólitos da Formação Caboclo na Região de Morro do Chapéu: relatório de consultoria I. CPRM, Salvador.

Thrana, C., Talbot, M.R., 2006. High-frequency carbonate-siliciclastic cycles in the Miocene of the Lorca Basin (Western Mediterranean, SE Spain). Geologica Acta 4, 343-354.

Tucker, M., 1982. Storm-surge sandstones and the deposition of interbedded limestone: Late Precambrian, southern Norway. In: Einsele, G., Seilacher, A. (Eds.), Cyclic and event stratification. Springer-Verlag, Heidelberg, pp. 363-370.

Tucker, M.E., 2003. Mixed clastic-carbonate cycles and sequences: Quaternary of Egypt and Carboniferous of England. Geologia Croatica 56, 19-37.

Varejão, F.G., Fürsich, F.T., Warren, L.V., Matos, S.A., Rodrigues, M.G., Assine, M.L., Sales, A.M.F., Simões, M.G., 2019. Microbialite fields developed in a protected rocky coastaline: The shallow carbonate ramp of the Aptian Romualdo Formation (Araripe Basin, NE Brazil). Sed. Geol. 389, 103-120.

Walker, R.G., James, N.P., 1992. Facies models: response to sea level change. Geological Association of Canada, Newfoundland, Canada, p. 409 p..

Walter, M.R., 1977. Interpreting stromatolites. Am. Sci. 65, 563-571.

Yancey, T.E., 1991. Controls on carbonate and siliciclastic sediment deposition on a mixed carbonate-siliciclastic shelf (Pennsylvanian Eastern Shelf of north Texas). Kansas Geological Survey, Bulletin 233, 263-272.

Zecchin, M., 2007. The architectural variability of small-scale cycles in shelf and ramp clastic systems: The controlling factors. Earth Sci. Rev. 84, 21-55.

Zuffa, G.G., 1980. Hybrid arenites; their composition and classification. J. Sediment. Res. $50,21-29$. 